Published in final edited form as:

Methods Enzymol. 2016 ; 568: 303-350. doi:10.1016/bs.mie.2015.09.032.

\title{
Skin Keratins
}

Fengrong Wang ${ }^{\star}$, Abigail Zieman ${ }^{*}$, and Pierre A. Coulombe ${ }^{\star}, \dagger, \downarrow, \S, 1$

"Department of Biochemistry and Molecular Biology, Bloomberg School of Public Health, Johns Hopkins University, Baltimore, Maryland, USA

${ }^{\dagger}$ Department of Biological Chemistry, School of Medicine, Johns Hopkins University, Baltimore, Maryland, USA

¥Department of Dermatology, School of Medicine, Johns Hopkins University, Baltimore, Maryland, USA

§Department of Oncology, School of Medicine, Johns Hopkins University, Baltimore, Maryland, USA

\section{Abstract}

Keratins comprise the type I and type II intermediate filament-forming proteins and occur primarily in epithelial cells. They are encoded by 54 evolutionarily conserved genes ( 28 type I, 26 type II) and regulated in a pairwise and tissue type-, differentiation-, and context-dependent manner. Keratins serve multiple homeostatic and stress-enhanced mechanical and nonmechanical functions in epithelia, including the maintenance of cellular integrity, regulation of cell growth and migration, and protection from apoptosis. These functions are tightly regulated by posttranslational modifications as well as keratin-associated proteins. Genetically determined alterations in keratin-coding sequences underlie highly penetrant and rare disorders whose pathophysiology reflects cell fragility and/or altered tissue homeostasis. Moreover, keratin mutation or misregulation represents risk factors or genetic modifiers for several acute and chronic diseases. This chapter focuses on keratins that are expressed in skin epithelia, and details a number of basic protocols and assays that have proven useful for analyses being carried out in skin.

\section{INTRODUCTION}

\subsection{General Features of Keratin Genes, Proteins, and Filaments}

Keratins represent a major subclass within the large family of intermediate filament (IF) proteins, which self-assemble into 10-nm-wide filaments (Fuchs \& Weber, 1994). The genes encoding the 28 type I and 26 type II keratins are, respectively, clustered on chromosomes $17 q 21.2$ and 12q13.13, with the exception of the type I keratin 18 (Krt18), which is located next to Krt8 on the type II gene cluster (Hesse, Zimek, Weber, \& Magin, 2004; Fig. 1). The molecular features of keratin genes, such as size, number and positions of introns/exon junctions, transcriptional orientation, and positions relative to other family members are largely conserved in mammals, suggesting that keratin genes arose from duplication of an

\footnotetext{
${ }^{1}$ Corresponding author: coulombe @jhsph.edu.
} 
ancestral gene during evolution (Coulombe \& Bernot, 2004; Hesse et al., 2004). Keratins share the tripartite structure of all IF proteins: a highly conserved central a-helical rod domain flanked by highly variable nonhelical $\mathrm{N}$ - and $\mathrm{C}$-terminal head and tail domains (Fuchs \& Weber, 1994; Steinert, Steven, \& Roop, 1985; Fig. 2A). The N-terminal head and $\mathrm{C}$-terminal tail domains are dynamically subjected to numerous posttranslational modifications (Omary, Ku, Liao, \& Price, 1998; Pan, Hobbs, \& Coulombe, 2013; Snider \& Omary, 2014), which affect keratin filament assembly, organization, and interactions with other proteins (Haines \& Lane, 2012; Snider \& Omary, 2014; Toivola, Boor, Alam, \& Strnad, 2015).

In vitro studies have shown that keratin filament assembly begins with the formation of heterodimers from type I and type II keratin monomers, with the central rod domain S aligned in parallel and in register (Coulombe \& Fuchs, 1990; Hatzfeld \& Weber, 1990a). These heterodimers then interact along their lateral surfaces with an axial stagger and an antiparallel orientation, giving rise to structurally apolar tetramers. The latter further interact in an end-to-end and lateral fashion to give rise to 10-nm-wide filaments that are apolar, display a smooth surface, and contain on average 16 coiled-coil dimers in cross section (Herrmann, Wedig, Porter, Lane, \& Aebi, 2002; Fig. 2B). How IF assembly proceeds in living cells is poorly understood at present (Fig. 2C). A model based upon observations from time-lapse imaging of live epithelial cells in culture proposes that filament nucleation occurs at the cell periphery, with filament assembly proceeding as part of a centripetal flow culminating in the formation of a dense filament network that surrounds the nucleus (Windoffer, Beil, Magin, \& Leube, 2011). In its present form, this model does not account for how keratin filaments form stable arrays anchored at desmosome (cell-cell) and hemidesmosome (cell-matrix) junctions (Fig. 2D) - yet, these elements are crucial to the structural support and cytoarchitectural functions of keratin IFs.

\subsection{Keratin Gene Expression in Skin}

More than half of keratin genes are expressed in mature mammalian skin tissue. Keratin gene expression exquisitely reflects the type of epithelium (e.g., hair vs. epidermis), the differentiation state of epithelial cells and is subjected to striking modulation upon wounding, infection, or disease (Fuchs \& Green, 1980; Takahashi, Yan, Yamanishi, Imamura, \& Coulombe, 1998; Toivola et al., 2015; Woodcock-Mitchell, Eichner, Nelson, \& Sun, 1982). The interfollicular epidermis is a stratified epithelium consisting of a proliferative basal layer (progenitor status) that gives rise to multiple suprabasal layers (spinous, granular, and cornified) through a programmed differentiation process (Fuchs, 1995; Fig. 2E). Basal keratinocytes are mitotically active and express keratin 5 (K5; type II), K14, and minor amounts of K15 (both type I) (Fuchs \& Green, 1980; Lloyd et al., 1995; Nelson \& Sun, 1983; Fig. 2E-G). Upon their commitment to terminal differentiation, basal keratinocytes stop dividing and start expressing K1 (type II) and K10 (type I) concurrent with their migration upward into the suprabasal compartment (Byrne, 1997; Fuchs \& Green, 1980; Woodcock-Mitchell et al., 1982; Fig. 2E, F, and H). As they differentiate, epidermal keratinocytes undergo a dramatic flattening and begin accumulating keratohyalin granules, forming the granular layer (Holbrook \& Wolff, 1993). Additionally, expression of K2e, yet 
another type II keratin, is induced in the upper spinous and granular layers (Collin, Moll, Kubicka, Ooukayoun, \& Franke, 1992; Fig. 2E).

Keratingeneexpressioninpalmar-plantarepidermisisfarmorecomplicated than that of interfollicular epidermis. In this case, K9 (type I) is prominently expressed in the suprabasal, differentiating layers of stress-bearing regions, presumably to increase mechanical resilience (Langbein, Heid, Moll, \& Franke, 1993; Swensson et al., 1998; Fig. 2E). Further, K6 (type II), K16, K17, and K19 (all type I) are also expressed in specific spatial patterns (McGowan \& Coulombe, 1998b; Michel et al., 1996; Swensson et al., 1998). Interestingly, K6, K16, and $\mathrm{K} 17$ are rapidly and robustly induced upon various challenges to the interfollicular epidermis (e.g., wounding, infection), as well as in the setting of chronic hyperproliferative diseases (e.g., psoriasis and cancer) (Freedberg, Tomic-Canic, Komine, \& Blumenberg, 2001; McGowan \& Coulombe, 1998b; Paladini, Takahashi, Bravo, \& Coulombe, 1996; Stoler, Kopan, Duvic, \& Fuchs, 1988; Weiss, Eichner, \& Sun, 1984; Fig. 2E).

\subsection{Functions of Keratin Filaments and Their Associated Skin Disorders}

Keratin filaments impact cytoarchitecture and endow epithelial cells with their remarkable mechanical resilience and ability to withstand various forms of stresses (Coulombe, Hutton, Vassar, \& Fuchs, 1991; Fuchs, Esteves, \& Coulombe, 1992; Ma, Yamada, Wirtz, \& Coulombe, 2001; Seltmann, Fritsch, Kas, \& Magin, 2013). In vitro biophysical studies have shown that keratin filaments possess unique and remarkable viscoelastic properties that support their involvement in a structural support capacity (Ma et al., 2001). Mutations in keratin genes can reduce the strength of keratin filaments by disrupting filament formation, altering the properties and dynamics of keratin assemblies, and/or destabilizing junction proteins (Haines \& Lane, 2012; Omary, Coulombe, \& McLean, 2004) and ultimately result in disease. Examples of these skin fragility disorders include epidermolysis bullosa simplex (caused by mutations in K5 or K14), the first IF disorder to be discovered (Bonifas, Rothman, \& Epstein, 1991; Coulombe, Hutton, Letai, et al., 1991; Lane et al., 1992; Fig. 2IL), epidermolytic hyperkeratosis (mutations in K1, K10, or K9) (Lane \& McLean, 2004), and monilethrix (mutations in K81, K83, or K86) (McLean \& Moore, 2011).

Additionally, keratin filaments act as platforms that modulate cellular and molecular events including migration (Rotty \& Coulombe, 2012), innate immunity (Lessard et al., 2013; Roth et al., 2012; Tam, Mun, Evans, \& Fleiszig, 2012), hair cycling (Tong \& Coulombe, 2006), and tumor progression (Chung et al., 2015; Depianto, Kerns, Dlugosz, \& Coulombe, 2010; Hobbs et al., 2015) as well as other fundamental cell processes including growth and programed cell death (e.g., apoptosis) (Gilbert, Loranger, Daigle, \& Marceau, 2001; Inada et al., 2001; Kim \& Coulombe, 2007; Kim, Wong, \& Coulombe, 2006; Ku \& Omary, 2006). Mutations that possibly disrupt both structural and nonstructural roles of select keratins (K6, $\mathrm{K} 16$, or K17) underlie the cutaneous disorders pachyonychia congenita and steatocystoma multiplex (K17) (McLean \& Moore, 2011, McLean et al., 1995).

A keratin mutation database summarizing keratin variants and associated disorders is maintained at the Center for Molecular Medicine and the Bio-informatics Institute in Singapore and can be assessed online at http://www.interfil.org (Szeverenyi et al., 2008). 


\section{COLLECTION OF MOUSE SKIN TISSUE FOR ANALYSIS}

\subsection{Isolation of Mouse Skin Samples for Morphological Studies}

Skin tissue is easily accessible for the study of keratins in skin development and homeostasis. The epidermis of different body regions is not identical in architecture and morphological details; therefore, skin samples must be harvested from the same location (Montanez et al., 2007; Muller-Rover et al., 2001; Paus et al., 1999). Dorsal back skin is traditionally chosen for routine histology in mouse-another popular site for study is the ear. Animal euthanasia must be performed using an institutionally approved protocol.

2.1.1 Materials-Carbon dioxide euthanasia chamber (Nalgene); razor blades (VWR, cat. no. 55411-050); dissecting scissors; two forceps; sterile bacterial Petri dishes; isoflurane; propylene glycol; AcuPunch (Acuderm, Inc.); trimmer (Wahl ${ }^{\circledR}$ MiniARCO $^{\mathrm{TM}}$ ); liquid nitrogen; Bouin's solution (Sigma, cat. no. HT10132); small glass vials; ethanol; xylene; paraplast paraffin (Tyco Healthcare/Kendall, Hampshire, UK); microtome; Mayer's hematoxylin solution (Thermo Scientific, cat. no. TA-125-MH); eosin solution (Thermo Scientific, cat. no. 71504); Permount (Fisher Scientific, cat. no. SP15-100); sodium citrate; heat-resistant rack; normal goat serum (NGS); 4',6-diamidino-2-phenylindole (DAPI); 1× phosphate-buffered saline (PBS); ClearMount mounting media (Thermo Scientific, cat. no. 00-8110); optimal cutting temperature (OCT) compound (Sakura, Finetek); plastic embedding molds (Ted Pella, Inc., cat. no. 27112); cryostat (Thermo Scientific, Microm HM550); formaldehyde; paraformaldehyde (PFA); sucrose; EM-grade glutaraldehyde; sodium cacodylate; osmium tetroxide.

2.1.2 Harvesting Adult and Newborn Mice Skin Samples-For adult mice, if only a small skin sample (up to $5 \mathrm{~mm}$ punch biopsy) is required, anesthetize the animal with $20 \%$ $(\mathrm{v} / \mathrm{v})$ isoflurane in propylene glycol, and verify unconsciousness by gently pinching the footpad. If the animal responds, extend the anesthesia time or augment the anesthetic dosage. Use an AcuPunch to acquire a circular full-thickness skin biopsy (epidermis, dermis, and subcutaneous fat). If experiments call for a larger area of skin, or skin tissue from areas such as paws or whisker pads, sacrifice the animals with $\mathrm{CO}_{2}$ in a suitable chamber, and confirm euthanasia with cervical dislocation. Prior to tissue harvesting, remove the fur with a trimmer at the sites of interest. Lift the skin and make a full-thickness incision with scissors. Cut along both sides of the midline to obtain a rectangular sample of the back skin, while noting tissue orientation relative to the main body axis.

To obtain skin tissue from neonatal mice, sacrifice them by decapitation with surgical scissors. Remove the tail, genital area, and limbs with scissors. Cut along the dorsal surface from tail to neck and then peel off the skin from the body as one piece.

If skin samples are to be used for protein and ribonucleic acid (RNA) extraction, immediately snap-freeze them with liquid nitrogen if protein or RNA extraction cannot be performed at the time of harvest. If the tissue processing requires fixation, temporarily spread the skin tissue flat in a sterile Petri dish. This enables the tissue to adopt and maintain a flat shape during fixation and subsequent embedding. Trim the tissue to the proper size with a razor blade. 
2.1.3 Preparation of Skin Tissue for Routine Morphological Study-For histological analyses, tissues are sliced into thin $(5-10 \mu \mathrm{m})$ sections with either a microtome or a cryostat and stained to distinguish between different tissue components either with hematoxylin and eosin (H\&E) staining or with immunohistochemistry. Hematoxylin, a basic dye, stains acidic structures purple or blue (e.g., nuclear deoxyribonucleic acid (DNA), ribosomal RNA, and rough endoplasmic reticulum). Eosin, an acidic dye, stains basic structures pink (e.g., cytoplasmic components) (Fischer, Jacobson, Rose, \& Zeller, 2008). Both paraffin-embedded tissues and fresh-frozen tissues can be used for H\&E staining (Fig. 3A) or immunohistochemistry (Fig. 3B). Keratin antibodies used for immunofluorescence staining in our laboratory are summarized in Table 1.

Preparation of paraffin-embedded tissues:

\section{Fixation}

1. To prevent skin curling during fixation, spread it flat in a weigh boat with epidermis facing up and cover with Bouin's solution (Sigma) for 10-15 min.

2. Transfer the skin into a small glass vial. Fix skin samples $\left(0.5-1 \mathrm{~cm}^{3}\right)$ in Bouin's solution overnight at $4{ }^{\circ} \mathrm{C}$.

3. After overnight fixation, remove excess fixative with multiple $70 \%$ ethanol washes.

4. Trim tissue to the proper size, paying attention to the orientation of the specimen relative to the main body axis (rostral-caudal axis vs. dorsal-ventral axis).

5. Store samples temporarily at $4{ }^{\circ} \mathrm{C}$ in $70 \%$ ethanol before further processing.

\section{Dehydration and embedding}

1. Place tissue samples in $50 \%$ ethanol for $30 \mathrm{~min}$.

2. Transfer tissue to $75 \%$ ethanol for $30 \mathrm{~min}$.

3. Transfer tissue to $95 \%$ ethanol for $30 \mathrm{~min}$.

4. Wash twice with $100 \%$ ethanol for $15 \mathrm{~min}$.

5. Wash twice with xylene for $10 \mathrm{~min}$.

6. Place tissue samples in molten paraffin at $60{ }^{\circ} \mathrm{C}$ while stirring in a beaker for $20-30$ min. Repeat three times.

7. Add a small amount of fresh molten paraffin to the embedding mold. Cool the mold on ice to solidify.

8. Place the sample in the mold in the correct orientation. Fill the rest of the mold with molten paraffin to cover the sample and allow it to harden.

9. Section $5-10 \mu \mathrm{m}$ thick samples with a microtome.

\section{H\&E staining of paraffin sections}

1. Remove paraffin by incubating the slides in $65^{\circ} \mathrm{C}$ for $30 \mathrm{~min}$ and wash three times for 5 min with xylene. 
2. Rehydrate slides with two washes of $100 \%$ ethanol, one wash each of $95 \%, 70 \%$, and $50 \%$ ethanol and a final wash with $\mathrm{ddH}_{2} \mathrm{O}$. All washes are 2.5 min each.

3. Stain in Mayer's hematoxylin solution 5-10 min.

4. Wash with running tap water $20 \mathrm{~min}$.

5. Counterstain with eosin solution $1 \mathrm{~min}$.

6. Perform two 2 min $95 \%$ ethanol washes.

7. Perform two 2 min $100 \%$ ethanol washes.

8. Perform two 2 min xylene washes.

9. Mount slides with Permount (Fisher Scientific) and glass coverslips.

\section{Immunohistochemistry of paraffin sections}

1. Deparaffinize and rehydrate slides following steps $1-2$ in the H\&E staining protocol.

2. Perform antigen retrieval as needed. Boil $\sim 500 \mathrm{~mL}$ of $10 \mathrm{~m} M$ sodium citrate buffer (pH 6.0) (see Appendix). Remove the boiling solution from heat source and immediately add the slides to this solution in a heat-resistant rack. Incubate 5-10 $\min$.

3. Let the slides cool $30 \mathrm{~min}$.

4. Perform three 5 min $1 \times$ PBS washes.

5. Block unspecific binding with $5 \% \mathrm{NGS} / 1 \times \mathrm{PBS}$ for $30 \mathrm{~min}$ at room temperature.

6. Incubate with primary antibody (diluted in $2.5 \% \mathrm{NGS} / 1 \times \mathrm{PBS}$ ) for $1 \mathrm{~h}$ at room temperature or overnight at $4{ }^{\circ} \mathrm{C}$.

7. Perform three 5 min $1 \times$ PBS washes.

8. Incubate with secondary antibody (diluted in $2.5 \% \mathrm{NGS} / 1 \times \mathrm{PBS}$ ) for $1 \mathrm{~h}$ at room temperature.

9. Wash the slide(s) once with $1 \times$ PBS containing DAPI; (1:10,000).

10. Perform three 5 min $1 \times$ PBS washes.

11. Mount slides with ClearMount mounting media (Life Technologies) and glass coverslips.

\section{Preparation of Fresh Frozen Tissue Samples}

1. Fill plastic mold with enough OCT compound (Sakura, Finetek) to cover the tissue.

2. Place harvested tissue into OCT in the desired orientation. Avoid generating bubbles in the OCT. Bubbles will interfere with subsequent sectioning.

3. Transfer the mold onto dry ice to solidify the OCT. Tissues frozen in OCT can be stored at $-80^{\circ} \mathrm{C}$ for several months. 
4. Cut tissues to $5-10 \mu \mathrm{m}$ sections using a cryostat machine. Equilibrate tissue blocks in cryostat at least $30 \mathrm{~min}$ before sectioning. Tissue sections can be stored at $-20{ }^{\circ} \mathrm{C}$.

To process for various staining protocols, thaw tissue sections and air dry 10 min. For H\&E staining (Fig. 3A), fix the tissue with $10 \%$ formalin for $5 \mathrm{~min}$ on ice, wash three times with $\mathrm{ddH}_{2} \mathrm{O}$ and then follow steps 3-9 for H\&E staining of paraffin-embedded sections. For immunostaining and/or fluorescence staining (Fig. 3B), fix the tissue with 4\% PFA for 10 $\mathrm{min}$ at room temperature, and then follow the steps 4-11 for immunohistochemistry staining of paraffin-embedded sections.

\subsubsection{Preparation of Skin Tissue for In Situ Hybridization}

1. To prevent RNA degradation, fix tissue samples immediately in freshly made, RNAse-free $4 \%$ PFA in RNAse-free PBS overnight at $4{ }^{\circ} \mathrm{C}$.

2. Drain PFA and wash tissue with cold RNAse-free PBS $\left(4{ }^{\circ} \mathrm{C}\right)$ three times for $10-15$ $\min$.

3. Incubate tissue in RNAse-free $30 \%$ sucrose in RNAse-free PBS (w/v) overnight at $4{ }^{\circ} \mathrm{C}$.

4. Embed samples in OCT (Sakura, Finetek) and freeze them at least overnight at $-80{ }^{\circ} \mathrm{C}$.

5. Make sections of $10-15 \mu \mathrm{m}$ thickness.

6. Let slides air dry and store at $-80^{\circ} \mathrm{C}$ before hybridization process.

The procedures for the preparation of probes and their application for detecting specific keratin mRNAs in skin tissue sections have been described elsewhere (Tong \& Coulombe, 2004; Wang, Wong, Langbein, Schweizer, \& Coulombe, 2003).

\subsubsection{Preparation of Skin Tissue for Transmission Electron Microscopy-}

Compared with light microscopy, transmission electron microscopy (TEM) provides a significantly higher resolution view of biological elements. TEM can be used as a diagnostic and research tool for the characterization of the fine structure and organization of skin tissue and detect morphological defects at the subcellular level. A buffered solution containing PFA and glutaraldehyde is used as a primary fixative (Hayat, 2000).

1. Freshly prepare fixative solutions and prechill on ice.

2. Harvest tissue and fix overnight with $2 \%$ TEM-grade glutaraldehyde, $1 \%$ PFA prepared in $0.1 \mathrm{M}$ sodium cacodylate (pH 7.2) at $4{ }^{\circ} \mathrm{C}$.

3. On the following day, wash three times with $0.1 M$ sodium cacodylate (pH 7.2) at room temperature.

4. In a well-ventilated hood, postfix the tissue samples with $1 \%$ osmium tetroxide for $1 \mathrm{~h}$. Osmium tetroxide is hazardous to humans so wear gloves, facemask, and dispose of waste according to institutional guidelines for hazardous disposal. Note: 
tissue samples will become a dark brown/black color upon osmication, leading to a loss of histological cues.

5. Wash samples three times with $0.1 M$ sodium cacohylate ( $\mathrm{pH} 7.2)$.

6. Rinse samples three times with $\mathrm{ddH}_{2} \mathrm{O}$.

7. Transfer tissues to $50 \%$ ethanol and store at $4{ }^{\circ} \mathrm{C}$ before embedding (usually in an epoxy resin medium) using a standard TEM embedding protocol (Alvarado \& Coulombe, 2014; Lessard et al., 2013).

\subsection{Harvest Mouse Skin Samples for RNA and Proteins}

2.2.1 Materials—Razor blades (VWR, cat. no. 55411-050); TRIzol ${ }^{\circledR}$ Reagent (Life Technologies); $15 \mathrm{~mL}$ falcon tubes; Polytron hand-held homogenizer (Kinematica AG, Switzerland); chloroform; RNAse-free water; RNeasy kit (Qiagen); Bio-Rad protein assay dye reagent concentrate (Bio-Rad; cat. no. 500-0006); Albumin standard (Thermo Scientific, cat. no. 23209).

\subsubsection{Preparation and Analysis of RNA and Protein Samples from Tissues-} RNA and proteins from skin tissues are extracted using TRIzol ${ }^{\circledR}$ (TRIzol ${ }^{\circledR}$ Reagent, Life Technologies), which can be used to sequentially precipitate RNA, DNA, and proteins from the same sample.

\section{RNA extraction}

\section{RNA precipitation}

(10)
Cut the tissue into small pieces with a razor blade.

Transfer the tissue pieces into a $15-\mathrm{mL}$ falcon tube containing $1 \mathrm{~mL}$ of TRIzol ${ }^{\circledR}$ Reagent (Life Technologies).

Homogenize these tissue pieces for $1 \mathrm{~min}$ at room temperature.

Incubate the homogenate for $15 \mathrm{~min}$ at room temperature.

Add $0.2 \mathrm{~mL}$ of chloroform.

Shake the tube vigorously, by hand, for $15 \mathrm{~s}$.

Incubate the homogenate for $2-3 \mathrm{~min}$ at room temperature.

Centrifuge homogenate at $12,000 \times g$ for $15 \mathrm{~min}$ at $4{ }^{\circ} \mathrm{C}$.

Collect the upper aqueous phase with RNA. Save the organic phase for DNA and protein extraction.

Isolate RNA according to RNA isolation protocol (see TRIzol ${ }^{\circledR}$ protocol RNA Isolation procedure).

Resuspend RNA pellet in RNAse-free $\mathrm{ddH}_{2} \mathrm{O}$.

RNA should be purified by using an RNA clean-up kit (RNeasy kit; Lessard et al., 2013). 
The final RNA samples can be used for real-time quantitative reverse transcription polymerase chain reaction, Northern Blot analysis, etc.

\section{DNA precipitation: (must be completed before protein isolation)}

1. Refer to DNA precipitation procedure in TRIzol ${ }^{\circledR}$ protocol.

\section{Protein Isolation}

1. Follow protein isolation procedure in TRIzol ${ }^{\circledR}$ protocol until final resuspension step.

2. After $100 \%$ ethanol wash, resuspend protein pellet in $6.5 M$ Urea buffer (see Appendix) by adding $500 \mu \mathrm{L}$ of Urea buffer.

3. To optimize protein resuspension, rotate samples at $4{ }^{\circ} \mathrm{C}$ for $20 \mathrm{~min}$ to overnight.

4. Centrifuge samples at $10,000 \times g$ for $10 \mathrm{~min}$ at $4{ }^{\circ} \mathrm{C}$ to sediment any insoluble material.

5. Transfer supernatant containing protein to a new tube and measure protein concentration using Bradford assay. Isolated proteins can be subjected to western blot analysis. Keratin antibodies used for western blotting in our laboratory are summarized in Table 1.

\section{CELL CULTURE STUDIES}

Compared with in vivo studies, ex vivo cell culture provides a less complex setting that also enables the study specific cell populations, such as keratinocytes or fibroblasts, with potential for mechanistic insight. Thanks to continuous refinements in cell culture assays over the past 35 years, our understanding of the cellular and molecular basis underlying the proliferation, differentiation, migration, and death of epidermal keratinocytes has been greatly advanced (Lichti, Anders, \& Yuspa, 2008). The procedures described here can be routinely applied to isolate and culture keratinocytes harvested from newborn mouse skin.

\subsection{Materials}

Newborn (P0-P3) mice; two pair of forceps; dissecting scissors; povidone-iodine solution (Ricca Chemical Company, cat. no. 3955-16); ethanol; sterile bacteria Petri dish; 0.25\% trypsin (Corning, cat. no. 25-053-Cl); Dulbecco's modified Eagle's medium (DMEM; Gibco, cat. no. 11885-084); Lymphoprep ${ }^{\mathrm{TM}}$ (cat. no. 1114545); Cell scrapers; hemocytometer; Collagen type I (Corning, cat. no. 354236); $15 \mathrm{~mL}$ conical tubes; CnT-57 (CELLnTEC); KBM-2 (Lonza, cat. no. CC-3103); Chelex-100 resin (Bio-Rad, cat. no. 142-2842); 1× PBS; Whatman filter paper; calcium-free low glucose DMEM (US Biologicals, cat. no. D9800-10); sodium bicarbonate; penicillin-streptomycin (GIBCO/ Invitrogen, cat. no. 15140-122); calcium chloride; chamber slides (Lab-Tek, cat. no. 155380); culture insert (Ibidi, cat. no. 80209); Amaxa $^{\mathrm{TM}} 4 \mathrm{D}-$ Nucleofector $^{\mathrm{TM}}$ (Lonza); P1 Primary Cell 4D-Nucleofector ${ }^{\mathrm{TM}} \mathrm{X}$ Kit (Lonza); AcuPunch (Acuderm, Inc.); RNeasy kit (Qiagen); Nanophotometer (Implen); Bioruptor (Diagenode, UCD200); Bio-Rad protein 
assay dye reagent concentrate (Bio-Rad, cat. no. 500-0006); Albumin standard (Thermo Scientific, cat. no. 23209); Empigen BB (Calbiochem, cat. no. 324690); TrueBlot ${ }^{\circledR}$ AntiRabbit Ig IP Beads (Rockland, cat. no. 00-8800-25); TrueBlot ${ }^{\circledR}$ Anti-Rabbit-HRP (Rockland, 18-8816-31); $\beta$-mercaptoethanol.

\subsection{Isolation of Keratinocytes from Newborn Mouse Skin}

Generally, newborn pups between ages P0 (birth) and P3 are used as a source of skin keratinocytes for primary culture. If mice older than 3 days after birth are used, the keratinocyte yield will be low due to difficulties separating the epidermis from dermis due to hair follicle development (note that the epidermis gets thinner as the hair coat emerges at the surface of the skin).

1. On the first day, sacrifice pups via decapitation with scissors. Bathe them in iodine solution 2 min, wash twice with $\mathrm{ddH}_{2} \mathrm{O}$, and then rinse twice with $70 \%$ ethanol. All of the following steps should be performed inside a tissue culture hood using sterilized surgical tools.

2. Place pups into $10 \mathrm{~cm}$ bacterial Petri dishes. Hold mouse pup with a pair of forceps, cut off the front limbs at the ankle joint, and the hind limbs just below the joint, leaving visible stumps. This ensures that the skin harvested remains whole and intact, optimizing cell yield. Remove the tail close to the skin, leaving a hole. Keep a segment of the tail for genotyping.

3. Carefully insert scissors into the hole and cut skin along the dorsal surface of the mouse pup towards where the head was.

4. Use two pairs of forceps to carefully peel the skin off the mouse pup.

5. Place the skin onto a 6-cm sterile Petri dish, dermis side down, and carefully spread the skin flat so that the edges are not curled. If a large litter is being harvested and the skins need to rest for more than $45 \mathrm{~min}$, place dishes on ice until the next step.

6. Float skins (dermis facing down) on $4 \mathrm{~mL}$ of $0.25 \%$ trypsin in a 6-cm dish overnight (approximately 18 24 h) at $4{ }^{\circ} \mathrm{C}$.

7. Extract DNA from the tail snips and genotype by polymerase chain reaction (if relevant).

8. On day 2 , recover the floating skin samples from the trypsin solution with forceps, and place the skin, dermis side up, on the inner surface of the Petri dish lid.

9. Spread the skin flat, and remove the dermis by gently lifting it up straight from the epidermis. The dermis can be retained for fibroblast isolation.

10. Gently scrape keratinocytes away from the cornified layer of the epidermis with a (new) sterile cell scraper.

11. Add $3 \mathrm{~mL}$ of DMEM supplemented with $10 \%$ serum or mKER media (see Appendix) to collect keratinocytes, and transfer the resuspended cells into a 15-mL conical tube. Combine cells from (up to 3 ) mice of the same genotype. 
12. Pellet keratinocytes at $1200 \mathrm{rpm}$ for $5 \mathrm{~min}$ at $4{ }^{\circ} \mathrm{C}$, remove the supernatant and resuspend cells in $4 \mathrm{~mL}$ of fresh media. Thorough resuspension of keratinocytes is critical for a good yield.

13. Gently pipette cell suspension on top of $10 \mathrm{~mL}$ of Lymphoprep without disturbing the Lymphoprep/media interface.

14. Spin at $1800 \mathrm{rpm}$ for $30 \mathrm{~min}$ at $4{ }^{\circ} \mathrm{C}$. A white hazy layer enriched with keratinocytes can be seen after centrifugation.

15. Starting at the interface, collect all the media, along with the top $4 \mathrm{~mL}$ of Lymphoprep. Avoid disturbing the pellet of unwanted cells at the bottom.

16. Transfer the solution containing isolated keratinocytes into a fresh $15-\mathrm{mL}$ conical tube, and spin at $1200 \mathrm{rpm}, 5 \mathrm{~min}$ at $4{ }^{\circ} \mathrm{C}$.

17. Aspirate the supernatant and resuspend cells in the desired culture medium $(0.5 \mathrm{~mL}$ of media per pup).

18. Countcellsusingahemocytometerandplatecellsinsterileculturedishes. Precoating culture dishes with extracellular matrix proteins (e.g., Collagen type I) can facilitate cell attachment to the plate. Plating cells at $1.0 \times 10^{6}$ per $60 \mathrm{~mm}$ dish will yield around $80 \%$ confluence after $72 \mathrm{~h}$.

19. Change media the following day to remove dead cells and their secreted toxins.

\subsection{Conditions for the Primary Culture of Skin Keratinocytes}

Consistent with the existence of a $\mathrm{Ca}^{2+}$ gradient across the epidermis in skin tissue in situ, primary keratinocytes can be stimulated to differentiate by increasing $\mathrm{Ca}^{2+}$ concentration to $>0.07 \mathrm{~m} M$ in vitro (Lichti et al., 2008). Accordingly, much consideration needs to be taken when choosing culture media for experiments conducted on keratinocytes in primary culture.

\subsubsection{Growth Media for Keratinocytes in Primary Culture-For long-term}

maintenance, keratinocytes need to be grown on collagen-coated plates in fibroblastconditioned, low $\mathrm{Ca}^{2+}$ media. Reducing $\mathrm{Ca}^{2+}$ concentration facilitates the maintenance of keratinocytes in a basal layer like, relatively undifferentiated state. Media commonly used in our laboratory to culture keratinocytes for a limited period without passaging are mKer, CnT-57(CELLnTEC), FAD (Reichelt \& Haase, 2010; see Appendix), and KBM-2 (Lonza). mKer medium promotes proliferation of keratinocytes while inhibiting fibroblast growth, but because it has a high $\mathrm{Ca}^{2+}$ concentration, the majority of keratinocytes will differentiate within a few days postplating. Consequently, alternative media with low to negligible levels of $\mathrm{Ca}^{2+}$ are increasingly applied in routine studies in the laboratory. The CnT-57 medium $\left(0.07 \mathrm{mMCa}{ }^{2+}\right)$ is commercially available and formulated to retain the basal state of progenitor cells and delay their differentiation. FAD medium has similar supplements as mKer medium, but uses calcium-free DMEM and calcium-depleted fetal bovine serum (FBS). KBM-2 medium $\left(0.15 \mathrm{mMCa}{ }^{2+}\right)$, without additional growth factors, can also be used to culture keratinocytes for the short term, but keratinocytes proliferate very slowly in this medium. Low calcium media such as CnT-57 and FAD are recommended if the intent is 
to promote the proliferation and expansion of keratinocytes while minimizing differentiation.

\subsubsection{Calcium Switch Protocol to Induce Keratinocyte Differentiation-}

Keratinocytes usually proliferate readily under low calcium conditions $(0.05 \mathrm{mM})$ but will commit to terminal differentiation when the calcium concentration is $>0.07 \mathrm{mM}$. The differentiation status of keratinocytes can be assessed by morphological changes (flattening, increased surface area), formation of tight cell-cell adhesions, and expression of differentiation markers (e.g., K1, K10, involucrin, filaggrin, and loricrin) (Candi, Schmidt, \& Melino, 2005; Yuspa, Kilkenny, Steinert, \& Roop, 1989). This section provides procedures for preparing media with varying calcium concentrations, as well as performing the calcium switch (Lichti et al., 2008).

\section{Preparation of calcium-depleted serum}

1. Suspend $25 \mathrm{~g}$ Chelex-100 resin in $500 \mathrm{~mL}$ of $\mathrm{ddH}_{2} \mathrm{O}$.

2. Stir 5 min and gradually adjust $\mathrm{pH}$ to $\sim 7.4$.

3. Let the resin settle for 30 min without stirring.

4. Pour out $\mathrm{ddH}_{2} \mathrm{O}$.

5. Wash resin once with $1 \mathrm{~L}$ of fresh $\mathrm{ddH}_{2} \mathrm{O}$.

6. Wash resin twice with $1 \mathrm{~L}$ of $1 \times$ PBS.

7. In the last wash of PBS, adjust $\mathrm{pH}$ to 7.4. Pour off PBS.

8. Add the resin to $500 \mathrm{~mL}$ of FBS, stir mixture overnight at $4{ }^{\circ} \mathrm{C}$.

9. Filter the chelated FBS with Whatman filter paper.

10. Discard resin. Sterilize FBS in tissue culture hood with a $0.22-\mu \mathrm{m}$ filter.

\section{Preparation of calcium switch media}

1. Dissolve $4.885 \mathrm{~g}$ calcium-free low glucose DMEM powder (US Biologicals) in 500 $\mathrm{mL} \mathrm{ddH_{2 }} \mathrm{O}$.

2. Add $1.85 \mathrm{~g}$ sodium bicarbonate.

3. Sterilize media by filtration in tissue culture hood.

4. Supplement with chelated serum (8\% final) and penicillin-streptomycin $(0.5 \%$ final).

5. Use a sterile concentrated calcium chloride stock solution to obtain either low (0.05 $\mathrm{m} M$ ), moderate $(0.12-0.20 \mathrm{~m} M)$, or high $(1.2-2.0 \mathrm{~m} M)$ calcium media.

6. Calcium concentration can be verified using atomic absorption spectroscopy (Hennings, Holbrook, \& Yuspa, 1983).

\section{Calcium switch}

1. Plate keratinocytes in moderate calcium $(0.12-0.20 \mathrm{mM})$ overnight. 
2. On the next day, wash cells three times with calcium-free PBS, and then add low calcium medium $(0.05 \mathrm{~m} M)$.

3. Culture cells for $48 \mathrm{~h}$ or until confluent, and then induce them to differentiate using either moderate $(0.12-0.20 \mathrm{~m} M)$ or high $(1.2-2.0 \mathrm{~m} M)$ calcium media.

4. Continue culturing cells for another $24-48 \mathrm{~h}$ before harvesting cells for analysis.

3.3.3 Scratch Wounding Assay for Primary Keratinocytes-Scratch wounding, performed in confluent or near-confluent cultures of cells, represents a simple means to evaluate the migration properties of keratinocytes upon the appearance of the equivalent of a wound. Such wounds are created either by scratching a confluent monolayer of cells with a pipette tip or by plating cells into a chamber slide with a culture insert (Ibidi) and removing the insert when cells reach complete confluence, thus generating a gap. Cells at the newly generated "wound edge" will polarize and initiate migration to close the wound (Fig. 3C). Time-lapse imaging can capture cell migration at specific time points and ImageJ software can be used to quantitate migration velocity, directionality, and distance.

\subsubsection{Gene Transfer Protocols for Keratinocytes in Primary Culture-}

Transfection of primary keratinocytes is generally challenging because conventional methods such as liposome-mediated gene delivery result in low transfection efficiency while the calcium phosphate-based strategy induces keratinocytes to differentiate. Adenovirus can achieve nearly $100 \%$ transfection efficiency for transient expression in keratinocytes in primary culture while lentivirus- and retrovirus-based strategies have lower transfection efficiencies. A detailed viral transfection protocol has been described by Li (2013). This segment details a procedure involving the Lonza Primary Cell P1 kit, which gives rise to $\sim 50-60 \%$ transfection efficiency in mouse primary keratinocytes (Fig. 3D; Distler et al., 2005, Feng \& Coulombe, 2015).

1. Resuspend primary keratinocytes in culture media after isolation. Count cells.

2. Turn on the Amaxa ${ }^{\mathrm{TM}} 4 \mathrm{D}-\mathrm{Nucleofector}^{\mathrm{TM}}$, and select the Keratinocyte Mouse Primary program (CM-102).

3. Mix $16.4 \mu \mathrm{L}$ of nucleofection solution and $3.6 \mu \mathrm{L}$ of supplement solution from $\mathrm{P} 1$ Primary Cell 4D-Nucleofector ${ }^{\mathrm{TM}} \mathrm{X}$ Kit with $0.5 \mu \mathrm{g}$ of plasmid DNA.

4. Pellet $\sim 5 \times 10^{5}$ keratinocytes by centrifugation at $0.5 \times 1000 \mathrm{~g}$ for $5 \mathrm{~min}$ at $4{ }^{\circ} \mathrm{C}$.

5. Gently resuspend cell pellets in nucleofection mixture (see step 3).

6. Transfer the entire mixture into one well in the 16-well strip (included in nucleofection kit).

7. Place the strip into the nucleofector. Begin program.

8. After electrical pulse, wait $5-10 \mathrm{~min}$. Add $80 \mu \mathrm{L}$ of culture media to the well. Gently transfer the cell suspension into a culture plate.

9. Wait $24-48 \mathrm{~h}$ after transfection before using cells for experimentation. 


\subsection{Culture of Skin Explants Ex Vivo}

The in vitro scratch-wounding assay can yield reproducible, sophisticated insight about cell migration but cannot mimic the cross talk that occurs between various cell types during epithelialization as it occurs in vivo. Our laboratory adapted a simple skin explant culture assay ex vivo that allows migration to proceed from a stratified epithelium, and otherwise, allows for interactions between keratinocytes and fibroblasts. A comprehensive description of this assay can be accessed in Mazzalupo, Wawersik, and Coulombe (2002).

1. Obtain the skin of newborn pups as described (see isolation of skin keratinocytes for primary culture).

2. Place the skin, dermis side down, onto a sterile Petri dish and spread flat.

3. Use a biopsy punch device to generate circular, full-thickness skin pieces and transfer biopsies to a 24-well tissue culture dish. Lay the biopsies flat, dermal side down.

4. Allow $\sim 10-15 \mathrm{~min}$ for explants to adhere to the plate. Add $250 \mu \mathrm{L}$ of mKer medium to moisten the tissue edges, but not cover the center of the explants.

5. On the next day, submerge explants by adding an additional $250 \mu \mathrm{L}$ of mKer media to each well. Keratinocytes will grow from the explant edges, outward as a stratified sheet, over the next several days.

6. Change media every 2 days for duration of the experiment, usually $6-8$ days (see Mazzalupo et al., 2002).

7. Cells making up the outgrowth can either be used for immunofluorescence staining or be harvested for RNA and protein analysis, after the original biopsy piece has been removed. These protocols are described in the following two sections.

\subsection{Immunofluorescence Staining of Cells in Culture}

The fixation and permeabilization method used for keratinocytes in primary culture is dependent upon the antigen of interest and the antibody being used. Our laboratory commonly uses two methods: methanol-fixation, and 4\% PFA fixation coupled with $0.5 \%$ Triton/PBS permeabilization (Fig. 3E). Methanol, an organic solvent, precipitates proteins to preserve cellular structure. It works best for detecting intermediate filaments and their associated proteins (Ma \& Lorincz, 1988). Immunostainings of cytosolic proteins are usually fixed with PFA. It is a cross-linking reagent that yields a better preservation of cell morphology, but may hinder the access of antibody to its epitope(s) on target protein(s).

\section{Methanol fixation}

1. Fix cells in methanol for $5 \mathrm{~min}$ at $-20^{\circ} \mathrm{C}$

2. Wash cells three times with PBS, 5 min each.

3. Perform steps 5-11 from Immunofluorescence of Adult Tissues protocol. 


\section{PFA fixation}

1. Fix cells in $4 \%$ PFA for $10 \mathrm{~min}$ at room temperature.

2. Wash cells three times with PBS, 5 min each.

3. Permeabilize cells with $0.5 \%$ Triton/PBS for $5 \mathrm{~min}$.

4. Wash cells three times with PBS, 5 min each.

5. Perform steps 5-11 from Immunofluorescence of Adult Tissues protocol

\subsection{Isolation and Analysis of RNA and Proteins from Keratinocytes in Culture}

For both RNA and protein assays, it is important to keep the density of cells between experiments relatively consistent as confluence is a critical factor that regulates cell differentiation and alters gene expression. RNA extraction can be performed using an RNA Isolation kit following the manufacturer's protocol (such as RNeasy kit; Lessard et al., 2013). After RNA isolation and clean-up, samples should be kept on ice to prevent RNA degradation. RNA concentration should be determined using Nanophotometer (Implen). If the RNA is not to be used immediately, it should be kept frozen at $-20^{\circ} \mathrm{C}$ (short-term) or $-70{ }^{\circ} \mathrm{C}$ (long-term storage).

Cellular proteins can be extracted as a whole cell lysate, or as subcellular fractions (e.g., soluble vs. insoluble pools (Fig. 4A); cytosolic vs. membrane proteins (Fig. 4B)). Protease and phosphatase inhibitors are added to the lysis buffer to preserve the size and posttranslational modification of proteins.

\section{Preparing whole cell lysate}

1. Culture cells to proper confluence.

2. Aspirate media and wash once with PBS.

3. Add whole-cell extraction buffer (6.5 MUrea) to lyse cells ( $200 \mu \mathrm{L}$ per well of a 6well dish).

4. Collect cell lysates by scraping cells with cell scraper and transfer to a new tube.

5. Incubate $20 \mathrm{~min}$ on a shaker at $4{ }^{\circ} \mathrm{C}$.

6. Sonicate lysate $5 \mathrm{~min}$ (alternating $30 \mathrm{~s} \mathrm{ON} / 30 \mathrm{~s} \mathrm{OFF}$ ) on "high" setting with Bioruptor (Diagenode).

7. Pellet sonicated samples at maximum speed $(16.1 \times 1000 \mathrm{~g})$ for $20 \mathrm{~min}$ at $4{ }^{\circ} \mathrm{C}$.

8. Collect supernatant and determine concentration of proteins using Bradford assay.

\section{Soluble versus insoluble protein fractionation (Fig. 4A)}

1. Lyse cells in RIPA buffer (see Appendix; Wong \& Coulombe, 2003).

2. Incubate lysates $30 \mathrm{~min}$ on a shaker at $4{ }^{\circ} \mathrm{C}$.

3. Centrifuge at maximum speed $(16.1 \times 1000 g)$ for $10 \mathrm{~min}$ at $4{ }^{\circ} \mathrm{C}$. 
4. Collect supernatant as the "RIPA-soluble fraction."

5. Wash the remaining pellet with RIPA buffer three times.

6. Add 6.5 MUrea buffer and incubate $20 \mathrm{~min}$ on a shaker at $4{ }^{\circ} \mathrm{C}$.

7. Sonicate the lysate 5 min (alternating 30 s ON/30 s OFF) on "high" setting Bioruptor (Diagenode).

8. Pellet at maximum speed $(16.1 \times 1000 \mathrm{~g})$ for $20 \mathrm{~min}$ at $4{ }^{\circ} \mathrm{C}$. Collect supernatant as "insoluble fraction," which contains many cytoskeletal proteins.

9. Measure protein concentration with Bradford assay.

\section{Cytosolic versus membrane protein fractionation (Fig. 4B)}

1. Lyse cells in $0.01 \%$ Digitonin buffer (see Appendix; Rotty \& Coulombe, 2012).

2. Incubate samples $10 \mathrm{~min}$ on a shaker at $4{ }^{\circ} \mathrm{C}$.

3. Centrifuge at maximum speed $(16.1 \times 1000 \mathrm{~g})$ for $1 \mathrm{~min}$.

4. Collect supernatant as "cytosolic fraction."

5. Wash remaining pellet three times with Digitonin buffer.

6. Resuspend pellet in $0.5 \%$ Triton X-100 buffer (see Appendix).

7. Incubate $20 \mathrm{~min}$ on a shaker at $4{ }^{\circ} \mathrm{C}$.

8. Centrifuge at maximum speed $(16.1 \times 1000 \mathrm{~g})$ for $1 \mathrm{~min}$.

9. Collect supernatant as "membrane fraction."

10. The remaining pellet can be resuspended in 6.5 MUrea buffer to collect the "insoluble fraction."

\subsection{Immunoprecipitation of Keratin Proteins from Cell Culture to Study Their Interacting Partners}

As keratins typically are the least soluble proteins in keratinocytes, immunoprecipitation (IP) of keratin proteins has been a challenge. Lowthert, $\mathrm{Ku}$, Liao, Coulombe, and Omary (1995) have successfully developed a method for immunoprecipitating keratin proteins using $2 \%$ Empigen BB or 1\% NP-40 buffer. Both detergents can maintain some protein-protein interactions and solubilize a fraction of keratins. Our laboratory has adapted the Lowthert protocol over time and currently uses $1 \%$ Triton X-100 containing 2\% Empigen BB for antigen extraction towards IP assays (Chung et al., 2015) (see Fig. 4C for an example of K16 coimmunoprecipitation (Co-IP) results). The main steps involved (specific to K17 Co-IPs) are as follows:

1. Grow two $10-\mathrm{cm}$ plates of keratinocytes in primary culture to about $90 \%$ confluence.

2. Aspirate the media. Perform the following steps on ice.

3. Wash cells with cold PBS. 
4. Use $500 \mu \mathrm{L}$ of $1 \%$ Triton $\mathrm{X}-100$ lysis buffer containing $2 \%$ Empigen $\mathrm{BB}$ (see Appendix) to lyse cells in each plate. Scrape cells into a new tube.

5. Incubate cell lysates for $5 \mathrm{~min}$ on a shaker at $4{ }^{\circ} \mathrm{C}$.

6. Pellet at maximum speed $(16.1 \times 1000 \mathrm{~g})$ for $5 \mathrm{~min}$ at $4{ }^{\circ} \mathrm{C}$.

7. Combine the supernatants from both plates. Measure protein concentration using Bradford assay using bovine serum albumin (BSA) as a standard.

8. Save $40 \mu \mathrm{L}$ of lysate and add $40 \mu \mathrm{L} 2 \times$ sodium dodecyl sulfate (SDS) sample buffer (with $5 \% \beta$-mercaptoethanol) as input. Boil on heat block $\left(95^{\circ} \mathrm{C}\right)$ for $5 \mathrm{~min}$.

9. Transfer the combined supernatants to a new tube and add $20 \mu \mathrm{L}$ of TrueBlot ${ }^{\circledR}$ Anti-Rabbit Ig IP Beads to the lysates. Incubate for $45 \mathrm{~min}$ on a shaker at $4{ }^{\circ} \mathrm{C}$ to "preclear" beads and prevent nonspecific binding.

10. Centrifuge until maximal speed $(16.1 \times 1000 g)$ at $4{ }^{\circ} \mathrm{C}$ in a benchtop microfuge.

11. Aliquot $500 \mu \mathrm{L}$ of the supernatant into a $1.5-\mathrm{mL}$ Eppendorf tube labeled "IP control" and another $500 \mu \mathrm{L}$ into another tube labeled "K17 IP."

12. Add $0.5 \mu \mathrm{L}$ of preimmune serum into the "IP control" sample and add $0.5 \mu \mathrm{L}$ of K17 antibody (McGowan \& Coulombe, 1998a) into the "K17 IP." Generally use 1 $\mu \mathrm{L}$ of $\mathrm{K} 17$ antibody for $1 \mathrm{mg}$ of lysate.

13. Incubate the mixture for $3 \mathrm{~h}$ on a shaker at $4{ }^{\circ} \mathrm{C}$. Add $25 \mu \mathrm{L}$ of TrueBlot ${ }^{\circledR}$ AntiRabbit Ig IP Beads into each tube. Incubate 45 min on a shaker at $4{ }^{\circ} \mathrm{C}$.

14. Centrifuge until maximum speed $(16.1 \times 1000 g)$ at $4{ }^{\circ} \mathrm{C}$.

15. Wash the beads in each tube with $500 \mu \mathrm{L}$ of $1 \%$ Triton $\mathrm{X}-100$ lysis buffer three times.

16. Add $20 \mu \mathrm{L}$ of $2 \times$ sample buffer (with $5 \% \beta$-mercaptoethanol) to the pelleted beads in each tube. Boil on a heat block $\left(95^{\circ} \mathrm{C}\right)$ for $5 \mathrm{~min}$.

17. Analyze samples by western blotting. Use TrueBlot ${ }^{\circledR}$ Anti-Rabbit-HRP secondary antibody when probing with rabbit primary antibodies.

\section{IN VITRO METHODS TO STUDY KERATIN PROTEINS}

In addition to skin tissue and cell culture settings, recombinant keratin proteins can be used to investigate the properties of keratins in vitro. Keratin proteins readily concentrate in inclusion bodies when expressed in recombinant forms in Escherichia coli, facilitating their subsequent purification (see below; Coulombe \& Fuchs, 1990). 10-nm keratin filaments can be reconstituted in vitro from purified type I and II keratins through a simple series of dialysis steps. By introducing mutations into such recombinant keratin proteins, the amino acid residues and protein domains that are crucial for proper filament formation can be assessed (Coulombe, Chan, Albers, \& Fuchs, 1990; Hatzfeld \& Weber, 1990a, 1990b). Furthermore, one can study direct interactions between keratin proteins, or keratin filaments, with target proteins using far-western or the cosedimentation assays. 


\subsection{Materials}

BL21 (DE3) competent cells; Luria Broth (LB) agar plates; isopropyl $\beta$-D-1thiogalactopyranoside (IPTG; Sigma, cat. no. 16758); lysozyme (Sigma, cat. no. L6876); magnesium chloride; manganese chloride; deoxyribonuclease (Roche, cat. no. 10104159001); $0.22 \mu \mathrm{m}$ filter (Millex-GV, cat. no. SLGV033RS); $60 \mathrm{~mL}$ Syringe (BD, cat. no. 309653); fast protein liquid chromatography (FPLC; AKTA purifier); HiTrap Q column (GE Healthcare, cat. no. 17-1154-01); Coomassie blue dye; Mono Q column (GE Healthcare, cat. no. 17-5166-01); centrifugal filter units (Millipore, cat. no. UFC801096); cellulose dialysis tubing (Fisher Scientific); air-driven ultracentrifuge (Beckman Coulter); Parafilm; paper 1\% uranyl acetate; electron microscopy (EM) grid (Electron Microscopy Sciences, cat. no. CF400CU50); TEM; sodium chloride; $1.5 \mathrm{~mL}$ Eppendorf tubes; nitrocellulose membrane (Bio-Rad, cat. no. 162-0115); Ponceau S solution (Sigma, cat. no. P7170); BSA powder; Tween 20 (Amresco, cat. no. M147); enhanced chemiluminescence (ECL) solution (GE Healthcare, cat. no. RPN2235); Fluorchem Q MultiImage ${ }^{\circledR}$ III.

\subsection{Expression and Purification of Keratin Proteins}

\section{Expression of recombinant keratin proteins}

1. Day 1: Transform the plasmid encoding the keratin protein of interest into a suitable strain of E. coli bacteria. Generally, we use BL21 (DE3) plysS competent cells for type II keratins (K1, K5, K6) and BL21 (DE3) competent cells for type I keratins $(\mathrm{K} 10, \mathrm{~K} 14, \mathrm{~K} 16, \mathrm{~K} 17)$. Plate bacteria freshly transformed with the relevant plasmid on LB agar plate containing desired antibiotic and incubate overnight at $37^{\circ} \mathrm{C}$.

2. Day 2: Toward the end of the day, inoculate $10 \mathrm{~mL}$ of $\mathrm{LB}$ medium supplemented with antibiotic (for positive selection) with a colony from step 1, to initiate a liquid culture. Let the starter culture grow overnight in a $37^{\circ} \mathrm{C}$ shaker.

3. Day 3: Inoculate $1 \mathrm{~L}$ of LB media (with selective antibiotic) with a 1:100 dilution of the starter culture (step 2). Grow bacteria until $\mathrm{OD}_{600}$ reaches $\sim 0.6$.

4. Induce expression of keratin proteins by adding $1 \mathrm{~mL}$ of $200 \mathrm{mg} / \mathrm{mL}$ IPTG and allow for protein expression for $4-5 \mathrm{~h}$ in a $37^{\circ} \mathrm{C}$ shaker.

5. Pellet cells by centrifuging at $4000 \mathrm{rpm}$ for $20 \mathrm{~min}$ at $4{ }^{\circ} \mathrm{C}$. The cell pellets can be stored at $-20^{\circ} \mathrm{C}$ until the next step.

\section{Preparation of inclusion body fractions}

1. Resuspend the cells in $60 \mathrm{~mL}$ of Bacteria Lysis Buffer (see Appendix).

2. Add $15 \mathrm{~mL}$ of $10 \mathrm{mg} / \mathrm{mL}$ lysozyme, mix well, and incubate $30 \mathrm{~min}$ on ice.

3. Freeze the cells on dry ice for $30 \mathrm{~min}$ and then thaw cells (preferably at room temperature, or in a $37^{\circ} \mathrm{C}$ incubator).

4. Repeat the freeze-thaw cycle twice (step 3). 
5. Prepare DNase solution by mixing $450 \mu \mathrm{L}$ of $1 M \mathrm{MgCl}_{2}$ and $45 \mu \mathrm{L}$ of $1 \mathrm{MMnCl}_{2}$ with $1 \mathrm{~mL}$ of $10 \mathrm{mg} / \mathrm{mL}$ DNase.

6. Add the DNase solution (step 5) to the lysates from step 4. Incubate the mixture on a shaker at room temperature for $1 \mathrm{~h}$. Then, transfer the mixture to a shaker in a cold room $\left(4^{\circ} \mathrm{C}\right)$ and incubate overnight.

7. On the next day, add $150 \mathrm{~mL}$ of Detergent I solution (see Appendix), mix well and incubate the mixture on a shaker in a cold room $\left(4{ }^{\circ} \mathrm{C}\right)$ for $10 \mathrm{~min}$.

8. Centrifuge at $7000 \mathrm{rpm}$ for $30 \mathrm{~min}$. Discard the supernatant.

9. Resuspend the pellet in $150 \mathrm{~mL}$ of Detergent II solution (see Appendix), incubate the mixture in a shaker at $4{ }^{\circ} \mathrm{C}$ for $10 \mathrm{~min}$ and centrifuge at $8000 \mathrm{rpm}$ for $30 \mathrm{~min}$.

10. Wash the pellet again with Detergent II solution (repeat step 9).

11. Store the pellets (inclusion body) at $-20^{\circ} \mathrm{C}$ (up to 2 months) until purification.

\section{Purification of keratin proteins}

1. Add $8 \mathrm{~mL}$ of Urea Buffer A solution (see Appendix) to the inclusion body prep. Incubate on a shaker in a cold room $\left(4^{\circ} \mathrm{C}\right)$ for $1-2 \mathrm{~h}$ or overnight.

2. Centrifuge at $14,000 \mathrm{rpm}$ for $10 \mathrm{~min}$. Filter the supernatant through a $0.22-\mu \mathrm{m}$ filter syringe(s).

3. Purify keratin proteins via "FPLC" (AKTA purifier) with a HiTrap Q column (GE Healthcare) using Urea Buffer A and Urea Buffer B (see Appendix). Keratin proteins are separated from other proteins by gradually increasing the percentage of Urea Buffer B at the expense of Urea Buffer A (Coulombe \& Fuchs, 1990; Wawersik, Paladini, Noensie, \& Coulombe, 1997).

4. Run collected fractions on $10 \%$ sodium dodecyl sulfate polyacrylamide gel electrophoresis (SDS-PAGE) gel and stain with Coomassie blue dye to evaluate the purity and integrity of proteins.

5. To increase purity, combine desired fractions containing keratin proteins from HiTrap Q purification (step 3) and purify again via FPLC with a Mono Q column (GE Healthcare). Before Mono Q purification, make sure to dilute the sample(s) 1/3 with Urea Buffer A (to decrease salt concentration) and adjust $\mathrm{pH}$ to 8.5 with $\mathrm{NaOH}$ (Coulombe \& Fuchs, 1990; Wawersik et al., 1997).

6. Collect fractions, run them on $10 \%$ SDS-PAGE gel, and stain with Coomassie blue to evaluate the purity and integrity of proteins. Protein concentration can be measured using the Bradford assay.

\subsection{In Vitro Assembly of Keratin Filaments}

\section{Formation of type I-type II keratin heterotypic complexes}

1. Mix an approximately equal molar ratio of purified type I and type II keratins. The preferred concentration of proteins is $0.2 \mu \mathrm{g} / \mu \mathrm{L}$ (or above). 
2. Incubate the mixture at room temperature for $1 \mathrm{~h}$.

3. Dilute the sample $1 / 3$ with $6 M$ Urea Buffer A and add one drop of $10 \mathrm{~N} \mathrm{NaOH}$.

4. Purify heterotypic complexes via FPLC using a Mono Q column (GE healthcare) as described above (Coulombe \& Fuchs, 1990; Wawersik et al., 1997). Such complexes will elute at a higher salt concentration (higher percentage of $6 M$ Urea Buffer B) relative to type II keratin monomers, and type I keratin monomers.

5. Collect fractions, run them on $10 \%$ SDS-PAGE gel, and stain with Coomassie blue to evaluate the purity and integrity of proteins. For the purpose of in vitro filament assembly assays, set aside (and pool) the fractions with highest purity and protein concentration $(>0.5 \mu \mathrm{g} / \mu \mathrm{L})$. As needed, proteins can be concentrated by using centrifugal filter units (Minipore) and centrifuging samples at $2500 \mathrm{rpm}$ at $4{ }^{\circ} \mathrm{C}$ until the sample reaches a suitable concentration.

This step enables the recovery of keratin heterotypic complexes with type I and II proteins in a perfect 1:1 molar ratio and, as a bonus, allows for the elimination of remaining protein impurities if present.

\section{Reconstitution of keratin intermediate filaments from purified proteins in vitro}

1. Rinse dialysis tubing (Fisher Scientific) in $\mathrm{dH}_{2} \mathrm{O}$ for at least $10 \mathrm{~min}$. Place $0.5-1$ $\mathrm{mL}$ of sample $(>0.25 \mu \mathrm{g} / \mu \mathrm{L}$ or above $)$ into the dialysis tubing. For the following dialysis procedures, the buffer needs to be $>1000 \times$ volume of the sample.

2. Dialyze the sample in $9 M$ Urea-containing assembly buffer (see Appendix; Feng \& Coulombe, 2015; Lee \& Coulombe, 2009) for $4 \mathrm{~h}$ at room temperature.

3. Dialyze the sample in $2 M$ Urea-containing assembly buffer (see Appendix) for $1 \mathrm{~h}$ at room temperature.

4. Dialyze the sample in $0 M$ Urea-containing final assembly buffer (see Appendix) in a cold room $\left(4^{\circ} \mathrm{C}\right)$ overnight.

\subsection{High-Speed Sedimentation Assay and TEM}

High-speed sedimentation assay is used to assess the polymerization efficiency of keratin proteins. The ultrastructure of keratin filaments can be examined by negative staining ( $1 \%$ uranyl acetate) and with TEM (Coulombe \& Fuchs, 1990; Ma et al., 2001).

\section{High-speed sedimentation assay}

(1)
Take $100 \mu \mathrm{L}$ of sample after the last dialysis step (step 5 from filament assembly) and centrifuge at $150,000 \times g$ for $30 \mathrm{~min}$ using an Air-Driven tabletop Ultracentrifuge (Beckman Coulter).

Transfer supernatant (soluble pool) to a new tube and resuspend pellet (10-nm filaments) in $100 \mu \mathrm{L}$ of $2 \times$ SDS sample buffer.

Mix $5 \mu \mathrm{L}$ of input (before dialysis) with $5 \mu \mathrm{L}$ of $2 \times \operatorname{SDS}$. Mix $5 \mu \mathrm{L}$ of supernatant with $5 \mu \mathrm{L}$ of $2 \times \mathrm{SDS}$. Boil these samples at $95^{\circ} \mathrm{C}$ for 
$5 \mathrm{~min}$. Additionally, boil $5 \mu \mathrm{L}$ of resuspended pellet solution at $95^{\circ}$ $\mathrm{C}$ for $5 \mathrm{~min}$.

(4)

\section{TEM (Fig. 2B)}

(6)

(6)
Run samples from step 3 on 10\% SDS-PAGE gel and stain with Coomassie blue dye.

Intensity of the "supernatant" and "pellet" fractions can be quantified to evaluate filament formation efficiency. For K5-K14 samples, for example, $>95 \%$ of the input is typically retrieved in the pellet fraction, reflecting high assembly efficiency.

Apply $10 \mu \mathrm{L}$ of the dialyzed sample (filament assembly procedure) on a piece of Parafilm paper.

Place a drop of $\mathrm{dH}_{2} \mathrm{O}$ and two drops of $1 \%$ uranyl acetate separately on the Parafilm paper.

Place a carbon-coated, 400-mesh EM grid (Electron Microscopy Sciences) on the upper surface of the sample drop for $2 \mathrm{~min}$.

Place the grid on the surface of the $\mathrm{dH}_{2} \mathrm{O}$ drop for 5-10 s.

Place the grid on the surface of $1 \%$ uranyl acetate drop for $1 \mathrm{~min}$.

Place the grid on the surface of another $1 \%$ uranyl acetate drop for 1 $\min$.

Remove residual solution from the grid using filter paper, and let the grid dry.

Place the grid into a grid box.

Examine the grid by TEM using Philips BioTwin CM120 (FEI Company) or Hitachi 7600 (Hitachi) instruments (Lee \& Coulombe, 2009) to assess filament ultrastructure.

\subsection{Low-Speed Sedimentation Assay}

The formation of cross-linked keratin filaments can be assessed by low-speed sedimentation assay.

\section{Low-speed sedimentation assay}

1. To promote bundling of keratin filament assemblies, add $10 \mathrm{~m} M \mathrm{NaCl}$ to the $0 M$ Urea-containing, final buffer (filament assembly procedure) or lower the $\mathrm{pH}$ to 7.0. Dialyze the sample in a $4{ }^{\circ} \mathrm{C}$ cold room overnight.

2. Place $100 \mu \mathrm{L}$ of dialyzed sample in to a $1.5-\mathrm{mL}$ Eppendorf tube. Centrifuge at $8000 \times g$ for $30 \mathrm{~min}$. 
3. Transfer the supernatant into a new 1.5-mL Eppendorf tube and mix it with $100 \mu \mathrm{L}$ of $2 \times$ SDS sample buffer. Use $100 \mu \mathrm{L}$ of $2 \times$ SDS buffer to resuspend the pellet. Boil both the "supernatant" and "pellet" samples at $95{ }^{\circ} \mathrm{C}$ for $5 \mathrm{~min}$.

4. Run $10 \mu \mathrm{L}$ of the "supernatant" sample and $5 \mu \mathrm{L}$ of the "pellet" sample on $10 \%$ SDS-PAGE gel and stain with Coomassie blue dye.

5. Quantify the intensity of the "supernatant" and the "pellet" fractions. For K5-K14 samples, for example, $>50 \%$ of the input is typically retrieved in the pellet fraction, indicating a high degree of stable-filament-filament interactions (e.g., bundling).

As a complement to this say, keratin assemblies can be visualized using digital interference contrast light microscopy as described (Lee \& Coulombe, 2009).

\subsection{Far-Western Assay and Cosedimentation Assay to Study Direct Interactions}

While Co-IP assay provides a way to identify keratin protein(s) interacting partners, one of its limitations is that it does not distinguish between direct or indirect interactions.

Moreover, the bulk of keratin that is amenable to immunoprecipitation from cell lysates occur in the soluble pool, so the interaction of target proteins with keratin filaments cannot be studied using Co-IP. This section introduces the far-western assay and cosedimentation assay, which enable the investigation of direct interactions between target proteins with keratin proteins or keratin filaments, respectively (Lee \& Coulombe, 2009; Rotty \& Coulombe, 2012):

\section{Far-western assay (Fig. 4D)}

1. Run $5 \mu \mathrm{g}$ of each bait protein (e.g., purified recombinant keratin proteins: $\mathrm{K} 5$, K6, and K17) on a $10 \%$ SDS-PAGE gel.

2. Transfer the gel to a nitrocellulose membrane $(0.45 \mu \mathrm{m}$ pore size $)$.

3. Stain the membrane with Ponceau solution (Sigma) to assess protein loading.

4. Block the membrane in 5\% milk in $1 \times$ Tris-buffered saline with Tween 20 (TBST) for $30 \mathrm{~min}$.

5. Wash the membrane briefly with $1 \times$ TBST.

6. Incubate the membrane with the target protein, e.g., Src protein $(150 \mathrm{ng} / \mathrm{mL})$, in $5 \%$ BSA in $1 \times$ TBST on a shaker at room temperature for $4 \mathrm{~h}$.

7. Wash with $1 \times$ TBST several times.

8. Block the membrane in $5 \%$ milk in $1 \times$ TBST for $30 \mathrm{~min}$.

9. Incubate the membrane with primary antibody for the target protein (Src, 1:1000 dilution) in $5 \% \mathrm{BSA}$ in $1 \times \mathrm{TBST}$ on a shaker in a cold room $\left(4{ }^{\circ} \mathrm{C}\right)$ overnight.

10. Perform three 5 -min washes with $1 \times$ TBST.

11. Incubate the membrane with HRP-conjugated secondary antibody (1:2000 dilution) in 5\% milk in $1 \times$ TBST on a shaker at room temperature for $1 \mathrm{~h}$. 
12. Perform three 5 min washes with $1 \times$ TBST.

13. Apply ECL solution (GE Healthcare) and image the membrane with FluorchemQ system.

\section{In vitro cosedimentation assay (Rotty \& Coulombe, 2012)}

1. Dilute the protein of interest, e.g., Src protein (Abcam) in a suitable buffer (for Src: $60 \mathrm{~m} M$ HEPES, $\mathrm{pH} 7.5,5 \mathrm{~m} M \mathrm{MgCl}_{2}$, and $5 \mathrm{~m} M \mathrm{MnCl}_{2}$ ) to a $10 \mathrm{ng} / \mu \mathrm{L}$ final concentration.

2. After last step of dialysis with $0 M$ Urea-containing assembly buffer (see filament assembly protocol), incubate $25 \mu \mathrm{g}$ of the assembled keratin filaments with $100 \mathrm{ng}$ of target protein in a volume of final $100 \mu \mathrm{L}$.

3. As a negative control, incubate $25 \mu \mathrm{g}$ BSA with $100 \mathrm{ng}$ Src protein (Abcam) in a volume of $100 \mu \mathrm{L}$ of $(10 \mu \mathrm{L}$ of Src protein in Src kinase buffer, into $90 \mu \mathrm{L}$ of BSA in $0 M$ Urea buffer).

4. After mixing, immediately centrifuge the samples from steps 1 and 2 at $160,000 \times g$ for $30 \mathrm{~min}$ at room temperature.

5. Transfer the supernatant from each sample to a new separate tube and mix it with $100 \mu \mathrm{L}$ of $2 \times$ SDS sample buffer. Boil at $95^{\circ} \mathrm{C}$ for $5 \mathrm{~min}$.

6. Resuspend the pellet from each sample with $100 \mu \mathrm{L}$ of $2 \times$ SDS sample buffer and boil the mixture at $95^{\circ} \mathrm{C}$ for $5 \mathrm{~min}$.

7. Run $20 \mu \mathrm{L}$ of the "supernatant" fraction and $10 \mu \mathrm{L}$ of the "pellet" fraction from each sample on 10\% SDS-PAGE gel. Detect target protein (e.g., Src) via western blotting. If Src protein interacts with keratin filaments, a significant fraction of the Src protein should cosediment with filaments into the "pellet" fraction (Rotty \& Coulombe, 2012).

\section{PEARLS AND PITFALLS}

\subsection{Collection of Mouse Skin Tissue}

When harvesting skin from adult mice, the fur needs to be trimmed to avoid various complications related to its density and properties; care must be given to avoid wounding the skin. The time interval between skin isolation and fixation or snap freezing should be minimized to best preserve the original attributes of the tissue and its constituents.

\subsection{Morphological Studies}

The orientation of skin samples relative to the main body axis needs to be tracked during collection, embedding, and sectioning. Sectioning in a plane parallel to the rostral-caudal axis allows the viewing of single hair follicles along their long axis. Further, hair follicles cycle through growth (anagen), regression (catagen), and rest (telogen) phases, and therefore comparative experiments require skin tissue from the same phase (Montanez et al., 2007; Muller-Rover et al., 2001; Paus et al., 1999). 
Chemical fixation and paraffin embedding enable long-term storage of tissue samples with good preservation of tissue morphology, but may mask epitopes of target antigens of interest. Even with antigen retrieval, the use of paraffin sections for keratin antigen immunostaining is less sensitive than fresh-frozen sections. Fresh-frozen sections preserve most epitopes and are widely used for immunohistochemistry, but may not be ideal for morphological preservation because water frozen in the tissue could result in morphological changes (Stoppacciaro \& Ruco, 1999).

When preparing samples for TEM, it is important to fix tissue samples quickly because delayed and/or incomplete fixation may result in cellular damage (e.g., blebbing of the plasma membrane, swelling of extranuclear space, and abnormal mitochondrial cristae) (Graham \& Orenstein, 2007), thereby interfering with the assessment of the specific impact of genetic or other types of manipulation.

\subsection{Cell Culture Studies}

The viable cells recovered from dissected epidermal sheets represent a heterogeneous population consisting of basal keratinocytes, keratinocytes that originate from the upper segment of hair follicles (infundibulum and outer root sheath in particular; see Kamimura, Lee, Baden, Brissette, \& Dotto, 1997), melanocytes, and dermal fibroblasts. Though mKer medium can inhibit the growth of fibroblasts, fibroblasts generally have a higher proliferation rate than keratinocytes and can dominate the plate if keratinocytes are plated at low density. Keratinocytes do not grow well if they are seeded at low density.

As calcium is an important regulator of keratinocyte differentiation and other aspects of their biology, the concentration of this divalent cation in media needs to be carefully monitored. If interested in monitoring progression through terminal differentiation, a "moderate" amount of calcium in the medium is preferred to "high" calcium (Yuspa et al., 1989).

Keratinocytes form tight cell-cell adhesions and can detach as a sheet during scratchwounding assays, thus generating "wounds" of uneven characteristics so care should be taken when performing these assays. When preparing ex vivo skin explant culture, skin punches should be placed directly onto the dish. Moving the explant after placement on the dish will increase fibroblast outgrowth from the skin punch, and ultimately, their dominance in the dish.

\subsection{Isolation and Analysis of Proteins and RNA from Skin Cells and Tissues}

Tissues and cells should be processed quickly without going through multiple freeze-thaw cycles to prevent RNA and protein degradation. For RNA isolation, it is crucial to maintain an RNAse-free environment as RNAses are very stable, ubiquitous enzymes that do not require cofactors to function. Gloves must be worn at all times and changed frequently. Aerosol-barrier tips and disposable tubes are highly recommended throughout the procedure. Nondisposable containers and glassware need to be pretreated with diethyl pyrocarbonate, a strong RNAse inhibitor, before usage. For protein isolation, protease and phosphatase inhibitors should be added freshly every time to prevent degradation and preserve posttranslational modifications. 
Keratins exist as very stable type I-type II heterotypic complexes in vivo and in vitro even in the presence of Empigen BB, which partially solubilizes keratins. So when immunoprecipitating K17 from keratinocytes in culture other keratins such as K5, K6, and K14 will coimmunoprecipitate. The immunoglobulin G heavy chain $(\sim 55 \mathrm{kDa})$ falls in within the size range of most keratins $(40-60 \mathrm{kDa})$, so to avoid interference from the heavy chain we use TrueBlot ${ }^{\circledR}$ Anti-Rabbit Ig IP Beads to immunoprecipitate keratins using rabbit antibodies and TrueBlot ${ }^{\circledR}$ Anti-Rabbit-HRP secondary antibody to detect proteins by western blotting (Chung et al., 2015). Alternatively, cross-linking antibody to the beads can circumvent this problem, because the antibody will remain attached to the beads during protein elution (Bernot, Coulombe, \& Wong, 2004).

\subsection{In Vitro Studies with Recombinant Keratin Proteins}

The DNase digestion step is critical during the inclusion body preparation. If the digestion is not complete, the inclusion body will not pellet well during the Detergent I and II wash steps. A white viscous and fluffy pellet, instead of a solid white/amber pellet, will form as a result. Consequently, a large amount of the inclusion body will flow away when decanting the detergent after centrifugation, thereby significantly decreasing the keratin protein yield.

Serially decreasing the urea concentration from 9 to $0 M$ during keratin filament assembly is needed to allow for the successful formation of long and disperse $10 \mathrm{~nm}$ keratin filaments with high efficiency complexes (Herrmann et al., 2002). Concentration of keratin protein monomers should be higher than $0.2 \mu \mathrm{g} / \mu \mathrm{L}$ for best outcomes.

For the far-western assay, incubating the membrane with primary antibody longer than overnight, or washing with TBST solution for an excessive amount of time, may result in decreased signal of target proteins. One caveat for this assay is that the association tested may not reflect an in vivo interaction because the purified recombinant proteins immobilized on the membrane were first denatured during the preparation step by boiling in SDS sample buffer at $95^{\circ} \mathrm{C}$. Although these proteins partially renature when transferred onto the nitrocellulose membrane and incubated in gentler buffers, the resulting protein conformation may not approximate the native confirmation of the protein in the cell. Therefore, additional methods to test direct interactions are needed to support findings obtained from far-western assays.

\section{CONCLUSIONS}

Mouse skin represents a powerful model system to study the properties, regulation, and function of keratins in complex epithelia, whether normal or diseased. Further, skin tissue is readily amenable to clinical assessment, topical treatment, and survival surgery. Expression of keratin genes and proteins in skin follows established and evolutionary conserved patterns under healthy normal conditions, while disease processes are invariably accompanied by abnormal keratin regulation. Skin tissue thus makes it possible to investigate the roles of keratins in the complex setting of an intact, heterogeneous tissue. Cell culture, on the other hand, enables the study of the response of a single population of cells to a specific treatment and is amenable to gaining mechanistic insight. Keratinocytes represent the predominant cell type in primary culture, while fibroblasts also figure prominently in skin explant cultures. 
Insight gained from studies of keratinocytes in culture ex vivo can be readily related to their properties and functions in vivo. Additionally, recombinant keratin proteins can be used to study filament assembly as well as test for direct interactions between keratin proteins, or filaments, with other cellular proteins. In vitro studies using recombinant keratin proteins provide insight into how keratin proteins and filaments are functioning in vivo. We hope the methods and assays described here will prove useful for researchers interested in keratins and skin tissue.

\section{Acknowledgments}

We would like to thank Dr. Ryan P. Hobbs for proofreading this chapter and providing the in situ hybridization protocol. We are grateful to Dr. Jeremy Rotty for sharing the cosedimentation protocol and to Dr. Xia Feng for the negative staining protocol. Efforts in the laboratory are supported by grants AR042047, AR044232, and CA160255, from the National Institutes of Health, to P.A.C.

\section{ABBREVIATIONS}

\begin{tabular}{ll} 
BSA & bovine serum albumin \\
Co-IP & coimmunoprecipitation \\
DAPI & $4^{\prime}, 6$-diamidino-2-phenylindole \\
DMEM & Dulbecco's modified Eagle's medium \\
DNA & deoxyribonucleic acid \\
DNase & deoxyribonuclease \\
DTT & DL-dithiothreitol \\
ECL & enhanced chemiluminescence \\
E. coli & Escherichia coli \\
EDTA & ethylenediaminetetraacetic acid \\
EGF & epidermal growth factor \\
EGTA & ethylene glycol-bis(2-aminoethylether)-N,N, $\mathrm{N}^{\prime}, \mathrm{N}^{\prime}$ - \\
tetraacetic acid \\
EM & electron microscopy \\
FPLC & fast protein liquid chromatography \\
H\&E & hematoxylin and eosin \\
HRP & horseradish peroxidase \\
IF & intermediate filament \\
IPTG & isopropyl $\beta$-D-1-thiogalactopyranoside \\
\hline &
\end{tabular}




$\begin{array}{ll}\text { K } & \text { keratin (protein) } \\ \text { Krt } & \text { keratin (gene) } \\ \text { LB } & \text { Luria broth } \\ \text { NGS } & \text { normal goat serum } \\ \text { OCT } & \text { optimal cutting temperature } \\ \text { PBS } & \text { phosphate-buffered saline } \\ \text { PFA } & \text { paraformaldehyde } \\ \text { PIC } & \text { protease inhibitor cocktail } \\ \text { PIPES } & \text { 1,4-piperazinediethanesulfonic acid } \\ \text { PMSF } & \text { phenylmethylsulfonyl fluoride } \\ \text { RNA } & \text { ribonucleic acid } \\ \text { SDS } & \text { sodium dodecyl sulfate } \\ \text { SDS-PAGE } & \text { sodium dodecyl sulfate polyacrylamide gel } \\ & \text { electrophoresis } \\ \text { TBST } & \text { Tris-buffered saline with Tween 20 } \\ \text { TEM } & \text { transmission electron microscopy }\end{array}$

\section{References}

Alvarado DM, Coulombe PA. Directed expression of a chimeric type II keratin partially rescues keratin 5-null mice. The Journal of Biological Chemistry. 2014; 289:19435-19447. [PubMed: 24867950]

Bernot KM, Coulombe PA, McGowan KM. Keratin 16 expression defines a subset of epithelial cells during skin morphogenesis and the hair cycle. The Journal of Investigative Dermatology. 2002; 119:1137-1149. [PubMed: 12445204]

Bernot KM, Coulombe PA, Wong P. Skin: An ideal model system to study keratin genes and proteins. Methods in Cell Biology. 2004; 78:453-487. [PubMed: 15646628]

Bonifas JM, Rothman AL, Epstein EH Jr. Epidermolysis bullosa simplex: Evidence in two families for keratin gene abnormalities. Science. 1991; 254:1202-1205. [PubMed: 1720261]

Byrne C. Regulation of gene expression in developing epidermal epithelia. Bioessays. 1997; 19:691698. [PubMed: 9264251]

Candi E, Schmidt R, Melino G. The cornified envelope: A model of cell death in the skin. Nature Reviews Molecular Cell Biology. 2005; 6:328-340. [PubMed: 15803139]

Chung BM, Arutyunov A, Ilagan E, Yao N, Wills-Karp M, Coulombe PA. Regulation of C-X-C chemokine gene expression by keratin 17 and hnRNP K in skin tumor keratinocytes. The Journal of Cell Biology. 2015; 208:613-627. [PubMed: 25713416]

Collin C, Moll R, Kubicka S, Ooukayoun JP, Franke WW. Characterization of human cytokeratin 2, an epidermal cytoskeletal protein synthesized late during differentiation. Experimental Cell Research. 1992; 202:132-141. [PubMed: 1380918]

Coulombe, PA.; Bernot, KM. Keratins and the skin. In: Lennarz, WJ.; Lane, MD., editors. Encyclopedia of biological chemistry. Vol. 2. Oxford: Elsevier; 2004. p. 497-504. 
Coulombe, PA.; Bernot, KM.; Lee, CH. Keratins and the skin. In: Lennarz, WJ.; Lane, MD., editors. Encyclopedia of biological chemistry. Oxford: Elsevier; 2013. p. 665-671.

Coulombe PA, Chan YM, Albers K, Fuchs E. Deletions in epidermal keratins that lead to alterations in filament organization and assembly: In vivo and in vitro studies. The Journal of Cell Biology. 1990; 111:3049-3084. [PubMed: 1702787]

Coulombe PA, Fuchs E. Elucidating the early stages of keratin filament assembly. The Journal of Cell Biology. 1990; 111:153-169. [PubMed: 1694855]

Coulombe PA, Hutton ME, Letai A, Hebert A, Paller AS, Fuchs E. Point mutations in human keratin 14 genes of epidermolysis bullosa simplex patients: Genetic and functional analyses. Cell. 1991a; 66:1301-1311. [PubMed: 1717157]

Coulombe PA, Hutton ME, Vassar R, Fuchs E. A function for keratins and a common thread among different types of epidermolysis bullosa simplex diseases. The Journal of Cell Biology. 1991b; 115:1661-1674. [PubMed: 1721910]

Depianto D, Kerns ML, Dlugosz AA, Coulombe PA. Keratin 17 promotes epithelial proliferation and tumor growth by polarizing the immune response in skin. Nature Genetics. 2010; 42:910-914. [PubMed: 20871598]

Distler JH, Jungel A, Kurowska-Stolarska M, Michel BA, Gay RE, Gay S, et al. Nucleofection: A new, highly efficient transfection method for primary human keratinocytes. Experimental Dermatology. 2005; 14:315-320. [PubMed: 15810891]

Feng X, Coulombe PA. A role for disulfide bonding in keratin intermediate filament organization and dynamics in skin keratinocytes. The Journal of Cell Biology. 2015; 209:59-72. [PubMed: 25869667]

Fischer AH, Jacobson KA, Rose J, Zeller R. Hematoxylin and eosin staining of tissue and cell sections. CSH Protocols. 2008; 2008:prot4986. [PubMed: 21356829]

Freedberg IM, Tomic-Canic M, Komine M, Blumenberg M. Keratins and the keratinocyte activation cycle. The Journal of Investigative Dermatology. 2001; 116:633-640. [PubMed: 11348449]

Fuchs E. Keratins and the skin. Annual Review of Cell and Developmental Biology. 1995; 11:123153.

Fuchs E, Esteves RA, Coulombe PA. Transgenic mice expressing a mutant keratin 10 gene reveal the likely genetic basis for epidermolytic hyperkeratosis. Proceedings of the National Academy of Sciences of the United States of America. 1992; 89:6906-6910. [PubMed: 1379726]

Fuchs E, Green H. Changes in keratin gene expression during terminal differentiation of the keratinocyte. Cell. 1980; 19:1033-1042. [PubMed: 6155214]

Fuchs E, Weber K. Intermediate filaments: Structure, dynamics, function, and disease. Annual Review of Biochemistry. 1994; 63:345-382.

Gilbert S, Loranger A, Daigle N, Marceau N. Simple epithelium keratins 8 and 18 provide resistance to Fas-mediated apoptosis. The protection occurs through a receptor-targeting modulation. The Journal of Cell Biology. 2001; 154:763-773. [PubMed: 11514590]

Graham L, Orenstein JM. Processing tissue and cells for transmission electron microscopy in diagnostic pathology and research. Nature Protocols. 2007; 2:2439-2450. [PubMed: 17947985]

Haines RL, Lane EB. Keratins and disease at a glance. Journal of Cell Science. 2012; 125:3923-3928. [PubMed: 23104737]

Hatzfeld M, Weber K. The coiled coil of in vitro assembled keratin filaments is a heterodimer of type I and II keratins: Use of site-specific mutagenesis and recombinant protein expression. The Journal of Cell Biology. 1990a; 110:1199-1210. [PubMed: 1691189]

Hatzfeld M, Weber K. Tailless keratins assemble into regular intermediate filaments in vitro. Journal of Cell Science. 1990b; 97:317-324. [PubMed: 1703550]

Hayat, MA. Principles and techniques of electron microscopy: Biological applications. Cambridge, UK: Cambridge University Press; 2000.

Hennings H, Holbrook KA, Yuspa SH. Factors influencing calcium-induced terminal differentiation in cultured mouse epidermal cells. Journal of Cellular Physiology. 1983; 116:265-281. [PubMed: 6885930] 
Herrmann H, Wedig T, Porter RM, Lane EB, Aebi U. Characterization of early assembly intermediates of recombinant human keratins. Journal of Structural Biology. 2002; 137:82-96. [PubMed: 12064936]

Hesse M, Zimek A, Weber K, Magin TM. Comprehensive analysis of keratin gene clusters in humans and rodents. European Journal of Cell Biology. 2004; 83:19-26. [PubMed: 15085952]

Hobbs RP, DePianto DJ, Jacob JT, Han MC, Chung BM, Batazzi AS, et al. Keratin-dependent regulation of Aire and gene expression in skin tumor keratinocytes. Nature Genetics. 2015; 47:933-938. [PubMed: 26168014]

Holbrook, KA.; Wolff, K. The structure and development of skin. In: Fitzpatrick, TB.; Eisen, AZ.; WolV, K.; Freedberg, IM.; Austen, MD., editors. Dermatology in general medicine. New York: McGraw-Hill; 1993. p. 97-144.

Inada H, Izhawa I, Nishizawa M, Fujita E, Kiyono T, Takahashi T, et al. Keratin attenuates tumor necrosis factor-induced cytotoxicity through association with TRADD. The Journal of Cell Biology. 2001; 155:415-426. [PubMed: 11684708]

Kamimura J, Lee D, Baden HP, Brissette J, Dotto GP. Primary mouse keratinocyte cultures contain hair follicle progenitor cells with multiple differentiation potential. The Journal of Investigative Dermatology. 1997; 109:534-540. [PubMed: 9326386]

Kim S, Coulombe PA. Intermediate filament scaffolds fulfill mechanical, organizational, and signaling functions in the cytoplasm. Genes \& Development. 2007; 21:1581-1597. [PubMed: 17606637]

Kim S, Wong P, Coulombe PA. A keratin cytoskeletal protein regulates protein synthesis and epithelial cell growth. Nature. 2006; 441:362-365. [PubMed: 16710422]

$\mathrm{Ku}$ NO, Omary MB. A disease- and phosphorylation-related nonmechanical function for keratin 8 . The Journal of Cell Biology. 2006; 174:115-125. [PubMed: 16818723]

Lane EB, McLean WH. Keratins and skin disorders. The Journal of Pathology. 2004; 204:355-366. [PubMed: 15495218]

Lane EB, Rugg EL, Navsaria H, Leigh IM, Heagerty AH, Ishida-Yamamoto A, et al. A mutation in the conserved helix termination peptide of keratin 5 in hereditary skin blistering. Nature. 1992; 356:244-246. [PubMed: 1372711]

Langbein L, Heid HW, Moll I, Franke WW. Molecular characterization of the body site-specific human epidermal cytokeratin 9: cDNA cloning, amino acid sequence, and tissue specificity of gene expression. Differentiation. 1993; 55:57-71. [PubMed: 7507869]

Lee $\mathrm{CH}$, Coulombe PA. Self-organization of keratin intermediate filaments into cross-linked networks. The Journal of Cell Biology. 2009; 186:409-421. [PubMed: 19651890]

Lessard JC, Pina-Paz S, Rotty JD, Hickerson RP, Kaspar RL, Balmain A, et al. Keratin 16 regulates innate immunity in response to epidermal barrier breach. Proceedings of the National Academy of Sciences of the United States of America. 2013; 110:19537-19542. [PubMed: 24218583]

Li L. Mouse epidermal keratinocyte culture. Methods in Molecular Biology. 2013; 945:177-191. [PubMed: 23097108]

Lichti U, Anders J, Yuspa SH. Isolation and short-term culture of primary keratinocytes, hair follicle populations and dermal cells from newborn mice and keratinocytes from adult mice for in vitro analysis and for grafting to immunodeficient mice. Nature Protocols. 2008; 3:799-810. [PubMed: 18451788]

Lloyd C, Yu QC, Cheng J, Turksen K, Degenstein L, Hutton E, et al. The basal keratin network of stratified squamous epithelia: Defining K15 function in the absence of K14. The Journal of Cell Biology. 1995; 129:1329-1344. [PubMed: 7539810]

Lowthert LA, Ku NO, Liao J, Coulombe PA, Omary MB. Empigen BB: A useful detergent for solubilization and biochemical analysis of keratins. Biochemical and Biophysical Research Communications. 1995; 206:370-379. [PubMed: 7529499]

Ma ASP, Lorincz AL. Immunofluorescence localization of peripheral proteins in cultured human keratinocytes. The Journal of Investigative Dermatology. 1988; 90:331-335. [PubMed: 2450141]

Ma L, Yamada S, Wirtz D, Coulombe PA. A 'hot-spot' mutation alters the mechanical properties of keratin filament networks. Nature Cell Biology. 2001; 3:503-506. [PubMed: 11331879] 
Mazzalupo S, Wawersik MJ, Coulombe PA. An ex vivo assay to assess the potential of skin keratinocytes for wound epithelialization. The Journal of Investigative Dermatology. 2002; 118:866-870. [PubMed: 11982766]

McGowan KM, Coulombe PA. Onset of keratin 17 expression coincides with the definition of major epithelial lineages during skin development. The Journal of Cell Biology. 1998a; 143:469-486. [PubMed: 9786956]

McGowan, KM.; Coulombe, PA. The wound repair associated keratins 6, 16, and 17: Insights into the role of intermediate filaments in specifying cytoarchitecture. In: Harris, JR.; Herrmann, H., editors. Subcellular biochemistry: Intermediate filaments. London: Plenum Publishing Corp; 1998b. p. 141-165.

McLean WH, Moore CB. Keratin disorders: From gene to therapy. Human Molecular Genetics. 2011; 20:R189-R197. [PubMed: 21890491]

McLean WH, Rugg EL, Lunny DP, Morley SM, Lane EB, Swensson O, et al. Keratin 16 and keratin 17 mutations cause pachyonychia congenita. Nature Genetics. 1995; 9:273-278. [PubMed: 7539673]

Michel M, Torok N, Godbout MJ, Lussier M, Gaudreau P, Royal A, et al. Keratin 19 as a biochemical marker of skin stem cells in vivo and in vitro: Keratin 19 expressing cells are differentially localized in function of anatomic sites, and their number varies with donor age and culture stage. Journal of Cell Science. 1996; 109:1017-1028. [PubMed: 8743949]

Montanez E, Piwko-Czuchra A, Bauer M, Li S, Yurchenco P, Fassler R. Analysis of integrin functions in peri-implantation embryos, hematopoietic system, and skin. Methods in Enzymology. 2007; 426:239-289. [PubMed: 17697888]

Muller-Rover S, Handjiski B, van der Veen C, Eichmuller S, Foitzik K, McKay IA, et al. A comprehensive guide for the accurate classification of murine hair follicles in distinct hair cycle stages. The Journal of Investigative Dermatology. 2001; 117:3-15. [PubMed: 11442744]

Nelson WG, Sun TT. The 50- and 58-kdalton keratin classes as molecular markers for stratified squamous epithelia: Cell culture studies. The Journal of Cell Biology. 1983; 97:244-251. [PubMed: 6190820]

Omary MB, Coulombe PA, McLean WH. Intermediate filament proteins and their associated diseases. The New England Journal of Medicine. 2004; 351:2087-2100. [PubMed: 15537907]

Omary MB, Ku NO, Liao J, Price D. Keratin modifications and solubility properties in epithelial cells and in vitro. Sub-Cellular Biochemistry. 1998; 31:105-140. [PubMed: 9932491]

Paladini RD, Takahashi K, Bravo NS, Coulombe PA. Onset of re-epithelialization after skin injury correlates with a reorganization of keratin filaments in wound edge keratinocytes: Defining a potential role for keratin 16. The Journal of Cell Biology. 1996; 132:381-397. [PubMed: 8636216]

Pan X, Hobbs RP, Coulombe PA. The expanding significance of keratin intermediate filaments in normal and diseased epithelia. Current Opinion in Cell Biology. 2013; 25:47-56. [PubMed: 23270662]

Paus R, Muller-Rover S, Van Der Veen C, Maurer M, Eichmuller S, Ling G, et al. A comprehensive guide for the recognition and classification of distinct stages of hair follicle morphogenesis. The Journal of Investigative Dermatology. 1999; 113:523-532. [PubMed: 10504436]

Reichelt J, Haase I. Establishment of spontaneously immortalized keratinocyte lines from wild type and mutant mice. Methods in Molecular Biology. 2010; 585:59-69. [PubMed: 19907996]

Roop DR, Cheng CK, Titterington L, Meyers CA, Stanley JR, Steinert PM, et al. Synthetic peptides corresponding to keratin subunits elicit highly specific antibodies. The Journal of Biological Chemistry. 1984; 259:8037-8040. [PubMed: 6203901]

Roth W, Kumar V, Beer HD, Richter M, Wohlenberg C, Reuter U, et al. Keratin 1 maintains skin integrity and participates in an inflammatory network in skin through interleukin-18. Journal of Cell Science. 2012; 125:5269-5279. [PubMed: 23132931]

Rotty JD, Coulombe PA. A wound-induced keratin inhibits Src activity during keratinocyte migration and tissue repair. The Journal of Cell Biology. 2012; 197:381-389. [PubMed: 22529101]

Seltmann K, Fritsch AW, Kas JA, Magin TM. Keratins significantly contribute to cell stiffness and impact invasive behavior. Proceedings of the National Academy of Sciences of the United States of America. 2013; 110:18507-18512. [PubMed: 24167274] 
Snider NT, Omary MB. Post-translational modifications of intermediate filament proteins: Mechanisms and functions. Nature Reviews Molecular Cell Biology. 2014; 15:163-177. [PubMed: 24556839]

Steinert PM, Steven AC, Roop DR. The molecular biology of intermediate filaments. Cell. 1985; 42:411-420. [PubMed: 2411418]

Stoler A, Kopan R, Duvic M, Fuchs E. Use of monospecific antisera and cRNA probes to localize the major changes in keratin expression during normal and abnormal epidermal differentiation. The Journal of Cell Biology. 1988; 107:427-446. [PubMed: 2458356]

Stoppacciaro A, Ruco LP. Detection of adhesion molecules by immunohistochemistry on human and murine tissue sections. Methods in Molecular Biology. 1999; 96:93-106. [PubMed: 10098126]

Swensson O, Langbein L, McMillan JR, Stevens HP, Leigh IM, McLean WH, et al. Specialized keratin expression pattern in human ridged skin as an adaptation to high physical stress. The British Journal of Dermatology. 1998; 139:767-775. [PubMed: 9892940]

Szeverenyi I, Cassidy AJ, Chung CW, Lee BT, Common JE, Ogg SC, et al. The human intermediate filament database: Comprehensive information on a gene family involved in many human diseases. Human Mutation. 2008; 29:351-360. [PubMed: 18033728]

Takahashi K, Yan B, Yamanishi K, Imamura S, Coulombe PA. The two functional type II keratin 6 genes of mouse show a differential regulation and evolved independently from their human orthologs. Genomics. 1998; 53:170-183. [PubMed: 9790766]

Tam C, Mun JJ, Evans DJ, Fleiszig SM. Cytokeratins mediate epithelial innate defense through their antimicrobial properties. The Journal of Clinical Investigation. 2012; 122:3665-3677. [PubMed: 23006328]

Toivola DM, Boor P, Alam C, Strnad P. Keratins in health and disease. Current Opinion in Cell Biology. 2015; 32:73-81. [PubMed: 25599598]

Tong X, Coulombe PA. A novel mouse type I intermediate filament gene, keratin 17n (K17n), exhibits preferred expression in nail tissue. The Journal of Investigative Dermatology. 2004; 122:965-970. [PubMed: 15102087]

Tong X, Coulombe PA. Keratin 17 modulates hair follicle cycling in a TNFa-dependent fashion. Genes \& Development. 2006; 20:1353-1364. [PubMed: 16702408]

Wang Z, Wong P, Langbein L, Schweizer J, Coulombe PA. Type II epithelial keratin 6hf (K6hf ) is expressed in the companion layer, matrix, and medulla in anagen-stage hair follicles. The Journal of Investigative Dermatology. 2003; 121:1276-1282. [PubMed: 14675170]

Wawersik M, Paladini RD, Noensie E, Coulombe PA. A proline residue in the a-helical rod domain of type I keratin 16 destabilizes keratin heterotetramers and influences incorporation into filaments. The Journal of Biological Chemistry. 1997; 272:32557-32565. [PubMed: 9405470]

Weiss RA, Eichner R, Sun TT. Monoclonal antibody analysis of keratin expression in epidermal diseases: A 48- and 56-kdalton keratin as molecular markers for hyperproliferative keratinocytes. The Journal of Cell Biology. 1984; 98:1397-1406. [PubMed: 6201492]

Windoffer R, Beil M, Magin TM, Leube RE. Cytoskeleton in motion: The dynamics of keratin intermediate filaments in epithelia. The Journal of Cell Biology. 2011; 194:669-678. [PubMed: 21893596]

Wong P, Coulombe PA. Loss of keratin 6 (K6) proteins reveals a function for intermediate filaments during wound repair. The Journal of Cell Biology. 2003; 163:327-337. [PubMed: 14568992]

Woodcock-Mitchell J, Eichner R, Nelson WG, Sun TT. Immunolocalization of keratin polypeptides in human epidermis using monoclonal antibodies. The Journal of Cell Biology. 1982; 95:580-588. [PubMed: 6183275]

Yuspa SH, Kilkenny AE, Steinert PM, Roop DR. Expression of murine epidermal differentiation markers is tightly regulated by restricted extracellular calcium concentrations in vitro. The Journal of Cell Biology. 1989; 109:1207-1217. [PubMed: 2475508] 


\section{APPENDIX}

\section{Citrate buffer for antigen retrieval}

\begin{tabular}{|c|c|}
\hline $0.1 M$ Citric acid stock $\left(\mathrm{C}_{6} \mathrm{H}_{8} \mathrm{O}_{7} \cdot \mathrm{H}_{2} \mathrm{O}\right)$ & $21.0 \mathrm{~g}$ in $1 \mathrm{~L}$ \\
\hline $0.1 \mathrm{M}$ Sodium citrate stock $\left(\mathrm{C}_{6} \mathrm{H}_{5} \mathrm{Na}_{3} \mathrm{O}_{7} \cdot 2 \mathrm{H}_{2} \mathrm{O}\right)$ & $29.4 \mathrm{~g}$ in $1 \mathrm{~L}$ \\
\hline \multicolumn{2}{|c|}{$\begin{array}{l}\text { For } 500 \mathrm{~mL} \text { of } 0.01 M \text { citrate buffer, } \mathrm{pH} 6.0 \text {, add } 9 \mathrm{~mL} \text { of } 0.1 M \text { citric acid, } 41 \mathrm{~mL} \text { of } 0.1 M \text { sodium citrate, and bring } \\
\text { volume up to } 500 \mathrm{~mL} \text {. }\end{array}$} \\
\hline
\end{tabular}

6.5 M Urea buffer (for whole cell lysates and "insoluble fraction")

$50 \mathrm{~m} M$ Tris $(\mathrm{pH} 7.5)$
$1 \mathrm{~m} M$ EGTA
$6.5 M$ Urea
$2 \mathrm{~m} M$ DTT
$1 \mathrm{~m} M$ PMSF
$1 \times$ PIC1
$1 \times$ PIC2
$50 \mathrm{~m} M \mathrm{NaF}^{-}$
$1 \mathrm{~m} M \mathrm{Na}_{3} \mathrm{VO}_{4}$

\section{RIPA buffer (for "RIPA-soluble fractionation")}

$50 \mathrm{~m} M$ Tris $(\mathrm{pH} 7.5)$

$150 \mathrm{~m} M \mathrm{NaCl}$

$0.5 \mathrm{~m} M$ EDTA

$1 \mathrm{~m} M$ EGTA

$1 \%$ Triton X-100

$1 \%$ sodium deoxycholate

$0.1 \%$ SDS

$1 \mathrm{~m} M$ PMSF

$1 \times \mathrm{PIC} 1$

$1 \times \mathrm{PIC} 2$

$50 \mathrm{~m} M \mathrm{NaF}$

$1 \mathrm{~m} M \mathrm{Na}_{3} \mathrm{VO}_{4}$ 


\subsection{1\% Digitonin buffer (for "cytosolic fraction")}

$0.01 \%$ Digitonin

$10 \mathrm{~m} M$ PIPES (pH 6.8)

$300 \mathrm{~m} M$ Sucrose

$100 \mathrm{~m} M \mathrm{NaCl}$

$3 \mathrm{mM} \mathrm{MgCl}_{2}$

$5 \mathrm{~m} M$ EDTA

$0.2 \mathrm{~m} M$ DTT

$1 \mathrm{~m} M$ PMSF

$1 \times \mathrm{PIC} 1$

$1 \times \mathrm{PIC} 2$

$50 \mathrm{~m} M \mathrm{NaF}$

$1 \mathrm{~m} M \mathrm{Na}_{3} \mathrm{VO}_{4}$

$0.5 \%$ Triton buffer (for "membrane fraction")

$0.5 \%$ Triton X-100

$10 \mathrm{~m} M$ PIPES (pH 7.4)

$300 \mathrm{~m} M$ Sucrose

$100 \mathrm{~m} M \mathrm{NaCl}$

$3 \mathrm{mMMgCl} \mathrm{Mg}_{2}$

$3 \mathrm{~m} M$ EDTA

$0.2 \mathrm{~m} M \mathrm{DTT}$

$1 \mathrm{~m} M \mathrm{PMSF}$

$1 \times \mathrm{PIC} 1$

$1 \times$ PIC2

$50 \mathrm{~m} M \mathrm{NaF}$

$1 \mathrm{~m} M \mathrm{Na}_{3} \mathrm{VO}_{4}$

1\% Triton X-100 buffer containing 2\% Empigen BB (for IP keratins)

$40 \mathrm{~m} M$ HEPES (pH 7.5)

$120 \mathrm{mMNaCl}$

$1 \mathrm{~m} M$ EDTA 


\author{
$1 \%$ Triton $\mathrm{X}-100$ \\ $2 \%$ Empigen BB \\ $10 \mathrm{~m} M$ sodium pyrophosphate \\ $1 \mathrm{~m} M$ PMSF \\ $1 \times \mathrm{PIC} 1$ \\ $1 \times$ PIC2 \\ $50 \mathrm{~m} M \mathrm{NaF}$ \\ $1 \mathrm{~m} M \mathrm{Na}_{3} \mathrm{VO}_{4}$
}

\title{
Phenylmethylsulfonyl fluoride (PMSF)
}

Make $200 \mathrm{~m} M$ stock. Use at 1-2 mM concentration. (174.2 g/mol) Dissolve in isopropanol and store at $-20^{\circ} \mathrm{C}$. Warm stock to room temperature to resuspend precipitate immediately before use, PMSF has a half-life of $<1 \mathrm{~h}$ in aqueous solutions. Use extreme caution, as PMSF is highly toxic.

\section{Protease inhibitor cocktail 1 1000x (PIC1)}

\begin{tabular}{ll}
\hline $2 \mathrm{mg} / \mathrm{mL}$ & Antipain \\
\hline $10 \mathrm{mg} / \mathrm{mL}$ & Aprotinin \\
\hline $10 \mathrm{mg} / \mathrm{mL}$ & Benzamidine \\
\hline $1 \mathrm{mg} / \mathrm{mL}$ & Leupeptin \\
\hline Dissolve in sterile $\mathrm{ddH}_{2} \mathrm{O}$, aliquot, and store at $-20^{\circ} \mathrm{C}$ until use. \\
\hline
\end{tabular}

\section{Protease inhibitor cocktail 2 1000x (PIC2)}

\begin{tabular}{lc}
\hline $1 \mathrm{mg} / \mathrm{mL}$ & Cymostatin \\
\hline $1 \mathrm{mg} / \mathrm{mL}$ & Pepstatin-A \\
\hline Dissolve in dimethyl sulfoxide, aliquot, and store at $-20^{\circ} \mathrm{C}$ until use.
\end{tabular}

\section{mKer media}

\begin{tabular}{ll}
\hline DMEM Low Glucose & 3 parts \\
\hline Ham's F-12 & 1 part \\
\hline Fetal Bovine Serum & $10 \%$ \\
\hline Cholera toxin & $1 \mathrm{nM}$ \\
\hline Insulin & $5 \mu \mathrm{g} / \mathrm{mL}$ \\
\hline EGF & $10 \mathrm{ng} / \mathrm{mL}$ \\
\hline Gentamicin & $25 \mu \mathrm{g} / \mathrm{mL}$ \\
\hline
\end{tabular}




\begin{tabular}{ll} 
Hydrocortisone & $400 \mathrm{ng} / \mathrm{mL}$ \\
\hline Transferrin & $5 \mu \mathrm{g} / \mathrm{mL}$ \\
\hline 3,3',5-Triiodo-L-thyronine & $2 \mathrm{n} M$ \\
\hline Penicillin & $60 \mu \mathrm{g} / \mathrm{mL}$ \\
\hline
\end{tabular}

\section{FAD media}

\begin{tabular}{ll}
\hline Calcium-free DMEM & 3 parts \\
\hline Ham's F-12 & 1 part \\
\hline Fetal bovine serum (chelex-treated) & $10 \%$ \\
\hline Cholera toxin & $1 \mathrm{n} M$ \\
\hline Insulin & $5 \mu \mathrm{g} / \mathrm{mL}$ \\
\hline EGF & $10 \mathrm{ng} / \mathrm{mL}$ \\
\hline Gentamicin & $25 \mu \mathrm{g} / \mathrm{mL}$ \\
\hline Hydrocortisone & $400 \mathrm{ng} / \mathrm{mL}$ \\
\hline Penicillin & $60 \mu \mathrm{g} / \mathrm{mL}$ \\
\hline Adenine & $0.18 \mathrm{~m} M$ \\
\hline Glutamine & $2 \mathrm{~m} M$ \\
\hline Pyruvate & $1 \mathrm{~m} M$ \\
\hline
\end{tabular}

\section{Calcium switch media}

DMEM without $\mathrm{Ca}^{2+}$

8\% Chelated FBS

$0.5 \%$ Penicillin-streptomycin

Add desired amount of $\mathrm{Ca}^{2+}$ in the form of $\mathrm{CaCl}_{2}$ :

\begin{tabular}{ll}
\hline Low & $0.05 \mathrm{mM}$ \\
\hline Moderate & $0.12-0.20 \mathrm{mM}$ \\
\hline High & $1.2-2.0 \mathrm{mM}$ \\
\hline
\end{tabular}

\section{Bacterial lysis buffer}

\begin{tabular}{ll}
\hline Sucrose & $70 \mathrm{~m} M$ \\
\hline Tris- $\mathrm{HCl}(\mathrm{pH} 8.0)$ & $50 \mathrm{~m} M$ \\
\hline EDTA $(\mathrm{pH} 8.0)$ & $1 \mathrm{~m} M$ \\
\hline
\end{tabular}




\section{Detergent I}

\begin{tabular}{ll}
\hline Tris-HCl (pH 7.5) & $20 \mathrm{~m} M$ \\
\hline EDTA (pH 8.0) & $2 \mathrm{mM}$ \\
\hline $\mathrm{NaCl}$ & $0.2 \mathrm{M}$ \\
\hline Sodium deoxycholate & $1 \%$ \\
\hline Igepal CA-630 (or NP-40) & $1 \%$ \\
\hline
\end{tabular}

\section{Detergent II}

\begin{tabular}{ll}
\hline EDTA $(\mathrm{pH} 8.0)$ & $1 \mathrm{~m} M$ \\
\hline Triton X-100 & $0.5 \%$ \\
\hline
\end{tabular}

\section{Urea Buffer A (for keratin protein purification)}

\begin{tabular}{ll}
\hline Tris-HCl (pH 8.0) & $50 \mathrm{~m} M$ \\
\hline EGTA & $1 \mathrm{~m} M$ \\
\hline Urea & $6.5 M$ \\
\hline DTT (add freshly) & $2 \mathrm{~m} M$ \\
\hline PMSF (30 mg/mL in isopropanol; add freshly) & Use at 1/100 dilution \\
\hline Adjust pH to 8.5 before use. & \\
\hline
\end{tabular}

\section{Urea Buffer B (for keratin protein purification)}

Urea buffer A $\quad 300 \mathrm{~mL}$

Guanidine $\mathrm{HCl} \quad 0.5 \mathrm{M}$

\section{M Urea buffer (for filament assembly)}

\begin{tabular}{ll}
\hline Urea & $9 M$ \\
\hline Tris- $\mathrm{HCl}(\mathrm{pH} \mathrm{7.4)}$ & $25 \mathrm{~m} M$ \\
\hline$\beta$-Mercaptoethanol & $25 \mathrm{~m} M$ \\
\hline
\end{tabular}

\section{M Urea buffer (for filament assembly)}

\begin{tabular}{ll}
\hline Urea & $2 M$ \\
\hline Tris- $\mathrm{HCl}(\mathrm{pH} 7.4)$ & $5 \mathrm{~m} M$ \\
\hline B-Mercaptoethanol & $5 \mathrm{~m} M$ \\
\hline
\end{tabular}




\section{M Urea buffer (for filament assembly)}

Tris- $\mathrm{HCl}(\mathrm{pH} 7.5) \quad 5 \mathrm{mM}$

$\beta$-Mercaptoethanol $5 \mathrm{~m} M$ 
A

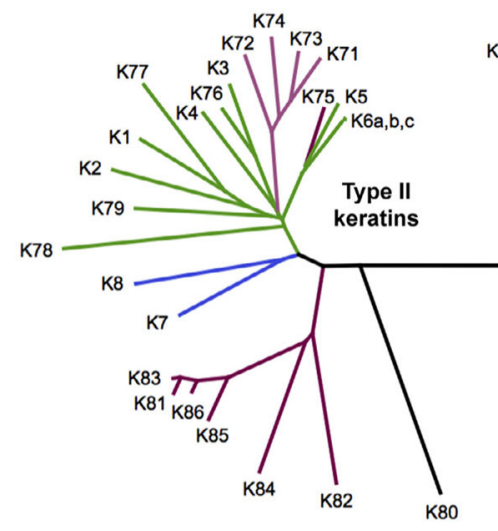

B

Type I keratin gene cluster-human chromosome $17 q 21.2$

centromere ... KRT222P KRT24 KRT223P $\quad$ KRT25 KRT26 KRT27 KRT28 KRT10 KRT12 KRT20 KRT23 KRT39 KRT40 KRT33A KRT33B KRT34 KRT31 KRT41P KRT37 KRT38 KRT221P KRT32 KRT35 KRT36 KRT13 KRT15 KRT19 KRT9 KRT14 KRT16 KRT17 KRT42P ... telomere

Type II keratin gene cluster - human chromosome 12q13.13

centromere ... KRT80 KRT7 KRT121P KRT122P KRT81 KRT86 KRT23 KRT123P KRT85 KRT84 KRT82 KRT124P KRT75 KRT6B KRT6C KRT6A KRT5 KRT71 KRT74 KRT72 KRT73 KRT125P KRT2 KRT1 KRT77 KRT126P KRT127P KRT128P KRT76 KRT3 KRT4 KRT79 KRT78 KRT8 KRT18 ... telomere

Figure 1.

The keratin gene family. (A) Comparison of the primary structure of human keratins using the ClustalW and TreeView softwares. Sequence relatedness is inversely correlated with the length of the lines connecting sequences, and number and position of branch points. This comparison makes use of the sequences from the head and central rod domain for each keratin. Two major branches are seen, corresponding exactly to the known partitioning of keratin genes into type I and type II sequences. Beyond this dichotomy, each subtype is further segregated into major subgroupings. (B) Location and organization of type I and type II keratin genes in the human genome. All functional type I keratin genes, except Krt18, are clustered on the long arm of human chromosome 17, while all functional type II keratin genes are located on the long arm of chromosome 12. Krt18, a type I gene, is located at the telomeric (Tel) boundary of the type II cluster. The suffix P identifies keratin pseudogenes. As highlighted by the color code used in frames A and B, individual type I and type II keratin genes belonging to the same subgroup, based on the primary structure of their protein products, tend to be clustered in the genome. Moreover, highly homologous keratin proteins (e.g., K5 and K6 paralogs; also, K14, K16, and K17) are often encoded by neighboring genes, pointing to the key role of gene duplication in generating keratin diversity. These features of the keratin family are virtually identical in mouse (not shown). Adapted from Coulombe, Bernot, and Lee (2013), figure 1. 

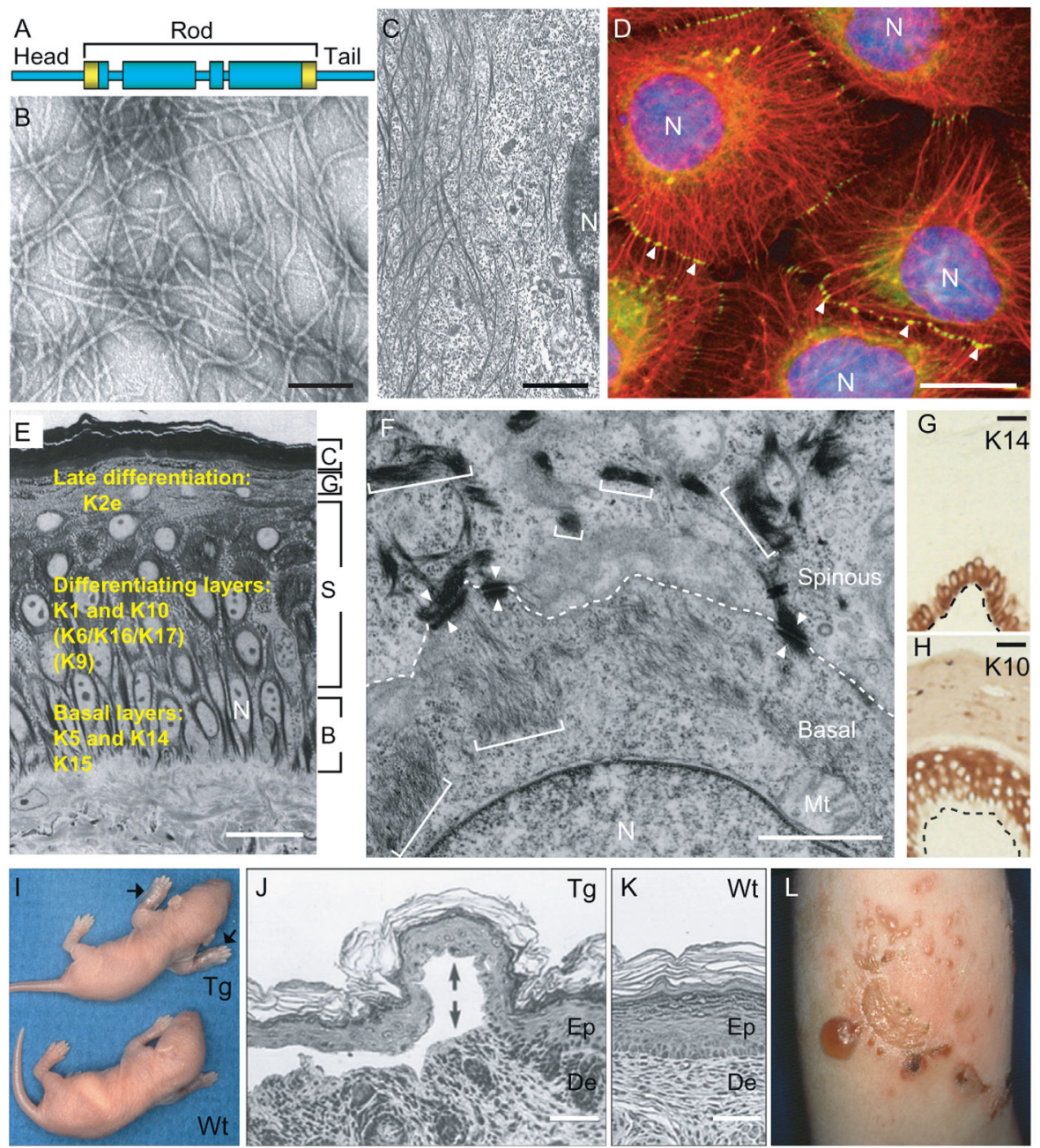

Figure 2.

Attributes, differential regulation, and disease association of keratins. (A) Tripartite domain structure shared by all keratin and other intermediate filament (IF) proteins. A central ahelical "rod" domain acts as a key determinant of self-assembly and is flanked by nonhelical "head" and "tail" domains at the N-terminus and C-terminus, respectively. The ends of the rod domain contain 15-20 amino acid regions, here shown is yellow that are highly conserved among all IFs. (B) Visualization of filaments, reconstituted in vitro from purified $\mathrm{K} 5$ and K14, by negative staining and electron microscopy. Bar, $125 \mathrm{~nm}$. (C) Ultrastructure of the cytoplasm of epidermal cells in primary culture as shown by transmission electron microscopy. Keratin filaments are abundant and tend to be organized in large bundles of loosely packed filaments in the cytoplasm. Bar, $5 \mu \mathrm{m}$. (D) Triple-labeling for keratin (red) and desmoplakin (green), a desmosome component, and DNA (blue) by indirect immunofluorescence of epidermal cells in culture. Keratin filaments are organized in a network that spans the entire cytoplasm and are attached to desmosomes at points of cellcell contacts (arrowheads). Bar, $30 \mu \mathrm{m}$. N, nucleus. (E) Histological cross section of resinembedded human trunk epidermis, revealing the basal (B), spinous (S), granular (G), and cornified (C) compartments. The differentiation-dependent distribution of keratin proteins in 
the epidermis is indicated. Bar, $50 \mu \mathrm{m}$. N, nucleus. (F) Ultrastructure of the boundary between the basal and suprabasal cells in mouse trunk epidermis as seen by routine transmission electron microscopy. The sample, from which this micrograph was taken, is oriented in the same manner as (E). Organization of keratin filaments as loose bundles (brackets in basal cell) correlates with the expression of K5-K14 in basal cells, whereas the formation of much thicker and electron-dense filament bundles (brackets in spinous cell) reflects the onset of K1-K10 expression in early differentiating keratinocytes. Arrowheads point to desmosomes. Bar, $1 \mu \mathrm{m}$. N, nucleus. $(\mathrm{G}$ and $\mathrm{H}$ ) Differential distribution of keratin epitopes on human skin tissue cross sections (similar to E) as visualized by an antibodybased detection method. K14 occurs in the basal layer, where the epidermal progenitor cells reside (G). K10 primarily occurs in the differentiating suprabasal layers of epidermis $(\mathrm{H})$. Dashed line, basal lamina. Bar, $100 \mu \mathrm{m}$. (I) Newborn mouse littermates. The top mouse is transgenic (Tg) and expresses a mutated form of K14 in its epidermis. Unlike the control pup below (Wt), this transgenic newborn shows extensive blistering of its front paws (arrows). ( $\mathrm{J}$ and $\mathrm{K})$ Hematoxylin and eosin (H\&E)-stained histological cross section through paraffin-embedded newborn mouse skin similar to those shown in (I). Compared with the intact skin of a control littermate $(\mathrm{K}, \mathrm{Wt})$, the epidermis of the $\mathrm{K} 14$ mutant expressing transgenic pup (J, Tg) shows intraepidermal cleavage within the basal layer, where the mutant keratin is expressed (opposing arrows). Bar, $100 \mu \mathrm{m}$. (L) Leg skin in a patient with the Dowling-Meara form of epidermolysis bullosa simplex. Several skin blisters are grouped in a herpetiform pattern. Reproduced from Coulombe \& Bernot, 2004. 

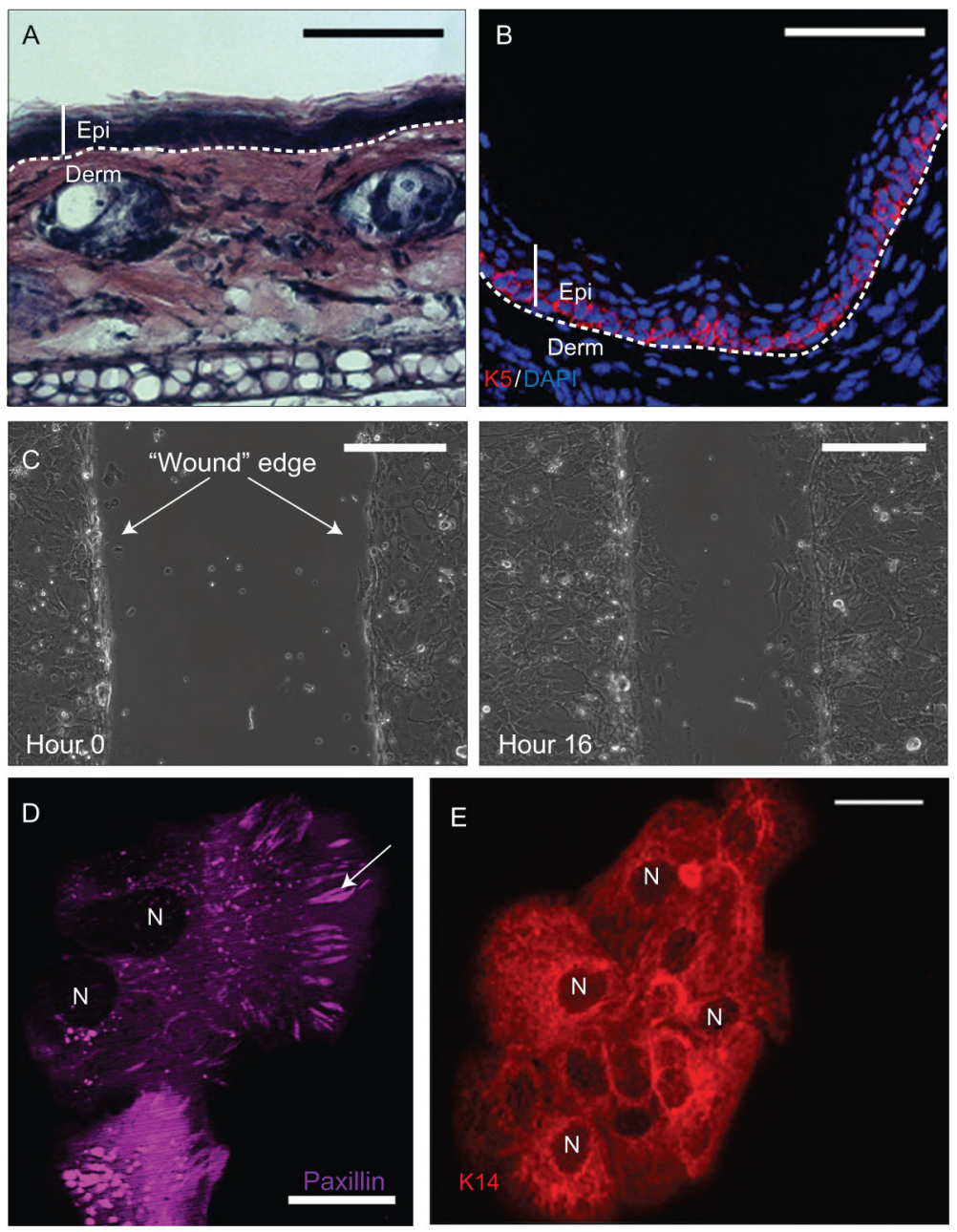

Figure 3.

Various analyses of skin keratins utilizing mouse tissue and cultured primary keratinocytes. (A) Hematoxylin and eosin stain of fresh-frozen adult mouse ear tissue (4 months old). Dotted line marks the boundary between the epidermis (Epi) and dermis (Derm). Bar, 50 $\mu \mathrm{m}$. (B) Fresh-frozen front paw tissue of a 2-month-old mouse processed for immunofluorescence of basal keratin K5. Note the restriction of K5 to the basal (progenitor) layer of keratinocytes. Dotted line marks the boundary between the epidermis (Epi) and dermis (Derm). Bar, $50 \mu \mathrm{m}$. (C) Live cell images of "wounding assay" using WT mouse keratinocytes in primary culture. Freshly isolated keratinocytes were plated in chamber slides with culture inserts. The "wound" was introduced by removing culture inserts when cells were $100 \%$ confluent. Phase contrast imaging was performed with a Zeiss Axio Observer Z1 microscope equipped with Zeiss EC Plan-Neofluar 10×/0.3 Ph1 objective for $16 \mathrm{~h}$. Bar, $200 \mu \mathrm{m}$. (D) Transient expression of mCherry fluorescence protein (mCherry)tagged paxillin in mouse primary keratinocytes. Freshly isolated keratinocytes were transfected with a plasmid encoding mCherry-tagged paxillin using the nucleofection method before plating in chamber slides with culture inserts. After removing the culture inserts, keratinocytes were allowed to migrate for at least $8 \mathrm{~h}$ before imaging using a Zeiss 
Axio Observer Z1 fluorescence microscope equipped with Zeiss EC Plan-Neofluar 40x objective. Keratinocytes shown in this panel were located at the leading edge in "wounding assay." Arrow points to a paxillin-positive focal adhesion. Bar, $20 \mu \mathrm{m}$. N, nucleus. (E) Immunofluorescence staining of keratin K14 in mouse skin keratinocytes in primary culture. Keratinocytes were isolated from newborn mouse pups and cultured in mKer media for 2 days. They were then fixed with $4 \%$ PFA and permeabilized with $0.5 \%$ Triton/PBS. Bar, 50 $\mu \mathrm{m}$. N, nucleus. 



Figure 4.

Subcellular fractionation methods and assays for studying keratin-interacting proteins. (A) Western blot analysis of Src activity (Y416 phosphorylated epitope) in WT, $K r t 6 a / b^{+/-}$, and $K r t 6 a / b^{-1-}$ skin explant keratinocyte protein lysates. Cellular outgrowths from skin explants cultured for 6 days were pooled and solubilized with RIPA buffer, and then with $6.5 M$ Urea buffer. Use of an antibody to K14 for western blotting reveals the relative amount of keratin protein occurring at the RIPA and urea extraction steps. $\beta$-Actin was used as a loading control for both RIPA-soluble fraction and RIPA-insoluble fraction (urea-soluble fraction). (B) Western blot analysis of subcellular localization of Rac1 in WT, Krt6a/b $\mathrm{b}^{+/-}$, and Krt6a/ $b^{-/-}$skin explant keratinocyte protein lysates. Cellular outgrowths from skin explants cultured for 6 days were pooled and solubilized with $0.01 \%$ Digitonin buffer and then with $0.5 \%$ Triton X-100 buffer. Loading was assessed using $\beta$-actin (digitonin-soluble fraction/ cytosolic fraction) and caveolin (triton-soluble fraction/membrane fraction). Use of an antibody to $\mathrm{K} 14$ for western blotting reveals the relative amount of keratin protein occurring at the RIPA and urea extraction steps. (C) Immunoprecipitation (IP) of keratin 16 (K16) from mouse keratinocytes in primary culture. Keratinocytes were isolated from newborn mouse pups and cultured to confluence before IP. "Input" represents the whole cell lysate, 
which serves as a positive control, "K16" refers to the K16 antibody (see Table 1) used for IP, and "PIS" refers to preimmune serum, used as a negative control. (D) Far-western assay to study the (direct) interaction between keratin proteins and, in this case, Src protein.

Recombinant K5, K6, and K17 proteins were purified using HiTrap Q column. $5 \mu \mathrm{g}$ of each of these keratin proteins were run on 10\% SDS-PAGE and transferred to a nitrocellulose membrane. Ponceau staining was done to assess loading of these proteins. The membrane was then incubated with recombinant Src protein $(150 \mathrm{ng} / \mathrm{mL}$; Abcam) for $4 \mathrm{~h}$ at room temperature. The association of Src protein with keratin proteins on the nitrocellulose membrane was next detected via conventional western blotting for Src protein. See Rotty and Coulombe (2012), for details. 
Wang et al.

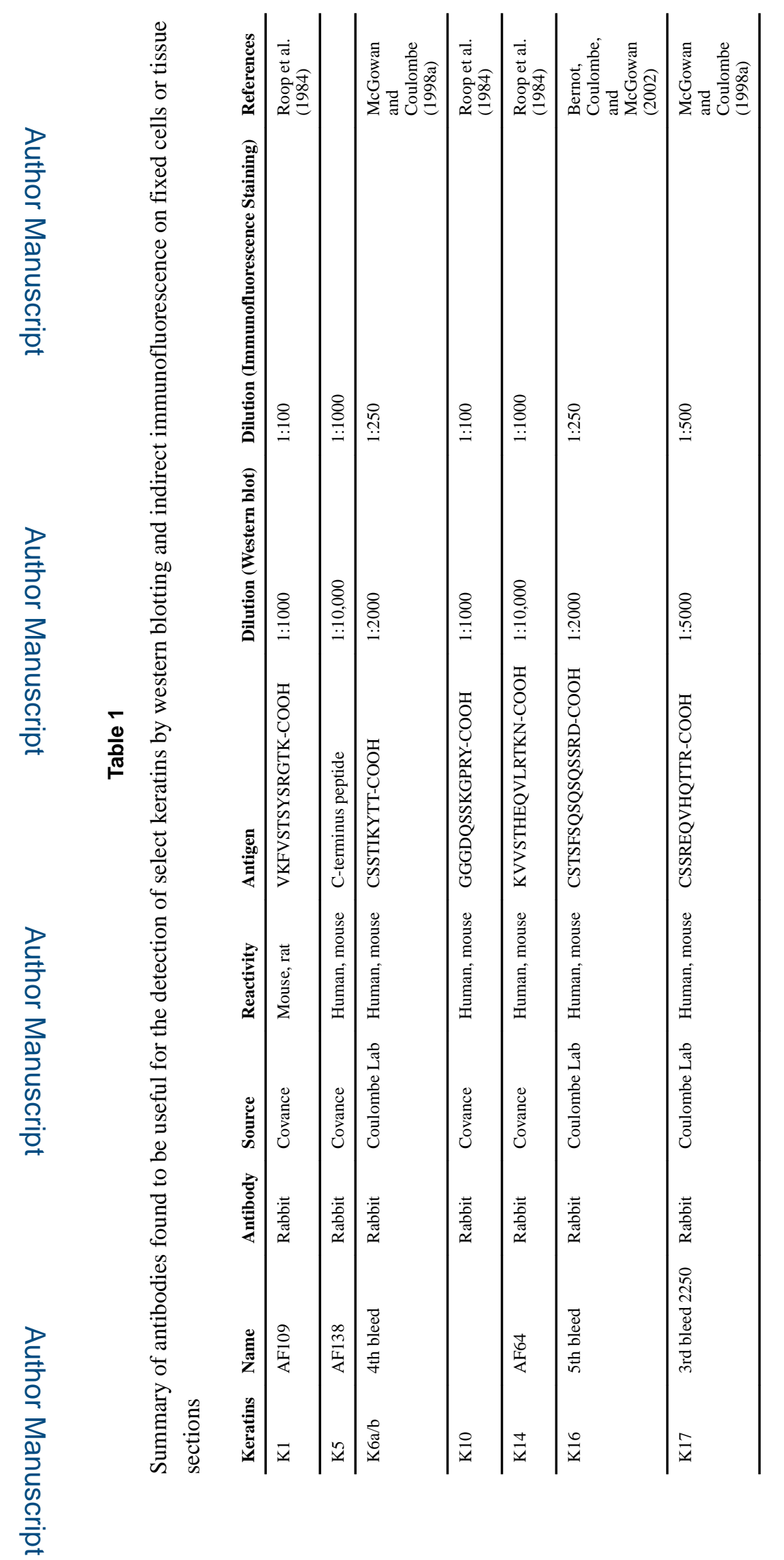

Methods Enzymol. Author manuscript; available in PMC 2016 June 11. 